Review

\title{
The Childhood-Onset Neurodegeneration with Cerebellar Atrophy (CONDCA) Disease Caused by AGTPBP1 Gene Mutations: The Purkinje Cell Degeneration Mouse as an Animal Model for the Study of this Human Disease
}

\author{
Fernando C. Baltanás ${ }^{1, *(\mathbb{D})}$, María T. Berciano ${ }^{2}$, Eugenio Santos ${ }^{1}(\mathbb{D})$ and Miguel Lafarga $^{3}$ \\ 1 Lab.1, CIC-IBMCC, University of Salamanca-CSIC and CIBERONC, 37007 Salamanca, Spain; esantos@usal.es \\ 2 Department of Molecular Biology and Centro de Investigación Biomédica en Red sobre Enfermedades \\ Neurodegenerativas (CIBERNED), University of Cantabria-IDIVAL, 39011 Santander, Spain; \\ berciant@unican.es \\ 3 Department of Anatomy and Cell Biology and Centro de Investigación Biomédica en Red sobre \\ Enfermedades Neurodegenerativas (CIBERNED), University of Cantabria-IDIVAL, 39011 Santander, Spain; \\ lafargam@unican.es \\ * Correspondence: baltanas@usal.es; Tel.: +34-923294801
}

Citation: Baltanás, F.C.; Berciano, M.T.; Santos, E.; Lafarga, M. The Childhood-Onset Neurodegeneration with Cerebellar Atrophy (CONDCA) Disease Caused by AGTPBP1 Gene

Mutations: The Purkinje Cell

Degeneration Mouse as an Animal Model for the Study of this Human Disease. Biomedicines 2021, 9, 1157. https://doi.org/10.3390/

biomedicines 9091157

Academic Editor: Kumar Vaibhav

Received: 16 August 2021

Accepted: 2 September 2021

Published: 4 September 2021

Publisher's Note: MDPI stays neutral with regard to jurisdictional claims in published maps and institutional affiliations.

Copyright: (c) 2021 by the authors. Licensee MDPI, Basel, Switzerland. This article is an open access article distributed under the terms and conditions of the Creative Commons Attribution (CC BY) license (https:// creativecommons.org/licenses/by/ $4.0 /)$

\begin{abstract}
Recent reports have identified rare, biallelic damaging variants of the AGTPBP1 gene that cause a novel and documented human disease known as childhood-onset neurodegeneration with cerebellar atrophy (CONDCA), linking loss of function of the AGTPBP1 protein to human neurodegenerative diseases. CONDCA patients exhibit progressive cognitive decline, ataxia, hypotonia or muscle weakness among other clinical features that may be fatal. Loss of AGTPBP1 in humans recapitulates the neurodegenerative course reported in a well-characterised murine animal model harbouring loss-of-function mutations in the AGTPBP1 gene. In particular, in the Purkinje cell degeneration ( $p c d$ ) mouse model, mutations in AGTPBP1 lead to early cerebellar ataxia, which correlates with the massive loss of cerebellar Purkinje cells. In addition, neurodegeneration in the olfactory bulb, retina, thalamus and spinal cord were also reported. In addition to neurodegeneration, $p c d$ mice show behavioural deficits such as cognitive decline. Here, we provide an overview of what is currently known about the structure and functional role of AGTPBP1 and discuss the various alterations in AGTPBP1 that cause neurodegeneration in the $p c d$ mutant mouse and humans with CONDCA. The sequence of neuropathological events that occur in $p c d$ mice and the mechanisms governing these neurodegenerative processes are also reported. Finally, we describe the therapeutic strategies that were applied in $p c d$ mice and focus on the potential usefulness of $p c d$ mice as a promising model for the development of new therapeutic strategies for clinical trials in humans, which may offer potential beneficial options for patients with AGTPBP1 mutation-related CONDCA.
\end{abstract}

Keywords: AGTPBP1; CCP1; CONDCA; neurodegeneration; NNA1; pcd

\section{Introduction}

Childhood-onset neurodegeneration with cerebellar atrophy (CONDCA; OMIM 618276) is a recently identified, rare and severe autosomal recessive disease that affects the central and peripheral nervous systems. Individuals present an early global developmental delay resulting in cognitive decline and motor performance alterations, among other clinical features [1-3]. The severity of the disease is variable, and CONDCA can even result in death during childhood. Whole exome sequencing studies on CONDCA patients have identified different damaging biallelic variants of the AGTPBP1 gene [1-4], linking AGTPBP1 loss of function to human neurodegenerative diseases. Nevertheless, the deleterious effects of AGTPBP1 protein loss of function in animal models, especially in mouse models, have been known for some time [5-11]. 
Two decades ago, studies characterising genes involved in axonal regeneration in mice led to the identification of a 4-kb-long transcript hotspot. Due to its proposed role and nuclear localization, the gene encoding this transcript was named Nna1 (Nervous system Nuclear protein induced by Axotomy) [7]. Although the precise role of the protein encoded by the AGTPBP1 gene remained elusive for several years, structural analysis of the AGTPBP1 protein revealed that it belonged to a new subfamily (M14D) of the M14 metallocarboxypeptidase family [12-14]. Subsequent functional analyses revealed that AGTPBP1, which acts as an enzyme, participates in post-translational modifications (PTMs) of tubulin. In particular, AGTPBP1 acts as a deglutamylase, catalysing the removal of polyglutamates at the C-terminal region of tubulin $[15,16]$. Other functions not directly related to tubulin processing, including maintenance of chromosomal stability and regulation of mitochondrial energy metabolism, were proposed for AGTPBP1 [17-19].

More than 40 years ago, the Purkinje cell degeneration $(p c d)$ mouse model, which harbours a mutation that is autosomal recessive and displays distinct neurological deficits, causing profound ataxic behaviour, was established [5]. After extensive studies, the mutant gene responsible for the pcd mutation was mapped to mouse chromosome 13 and identified as the AGTPBP1 gene [10].

The pcd mutation causes selective postnatal degeneration of certain neuronal populations, including the mitral cells (MCs) in the olfactory bulb (OB) [20], photoreceptors in the retina [6], certain subpopulations of thalamic neurons [21] and the Purkinje cells (PCs) in the cerebellum [10], the latter being responsible for the cerebellar ataxia of $p c d$ mice. Moreover, a recent analysis has revealed that these animals also undergo peripheral nerve and spinal motor neuron degeneration [1]. Similarly, recent works have shown that excessive tubulin polyglutamylation in neurons, which results from AGTPBP1 dysfunction, alters the axonal transport of vesicles and appears to be the main mechanism of neurodegeneration [22-24]. In addition to ataxia, $p c d$ mice also exhibit progressive cognitive impairments $[9,25]$.

Interestingly, the well-characterised neurological deficits in $p c d$ mice closely mimic the pathophysiology and clinical manifestations reported in CONDCA patients. Thus, the $p c d$ mouse is an ideal animal model for investigating other probable but not yet characterised clinical alterations in patients with CONDCA. Moreover, potential therapeutic options for preventing, or at least attenuating, the neurodegenerative course in CONDCA patients could be assessed using this animal model.

Here, we summarise the current knowledge about the structure and function of the AGTPBP1 gene in different cell types and tissues. We also review the variety of alterations in $\mathrm{mAGTPBP1}$ in $p c d$ mice and their relationships with the pathological variants of the hAGTPBP1 gene reported in CONDCA patients. Finally, we focus on the potential usefulness of the $p c d$ mouse model as a suitable model for the clinical assessment of new pharmacological strategies and therapies that may offer possible treatment options for patients with $A G T P B P 1$ mutation-induced CONDCA.

\section{The AGTPBP1 Gene}

\subsection{Genomic Structure and Organisation}

NNA1/AGTPBP1 contains a putative Walker A-box ATP/GTP binding motif (GXXGKS), which is highly conserved throughout evolution. According to the function and location of the protein encoded by this gene, it has also been called CCP1 (Cytosolic CarboxyPeptidase 1). Henceforth, we will use AGTPBP1 as the preferred term when referring to the gene or the protein.

The genomic regions occupied by the $A G T P B P 1$ locus vary widely between different organisms, but the intron/exon distribution of this gene is highly conserved. For example, the $\mathrm{h} A G T P B P 1$ gene is located on chromosome 9 (Chr 9q21.33 position: 85,546,539-85,742,029; 26 exons), whereas the $\mathrm{mAGTPBP1}$ gene is located on chromosome 13 (Chr13 position: $59,445,742-59,585,227 ; 26$ exons) (Figure 1A). 
A AGTPBP1 GENE

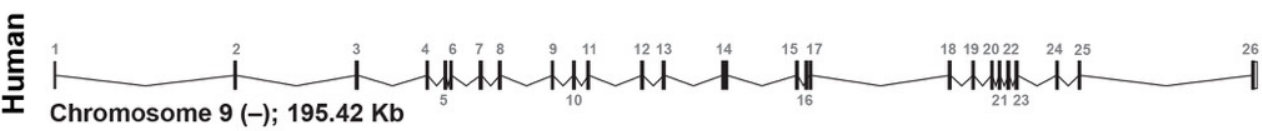

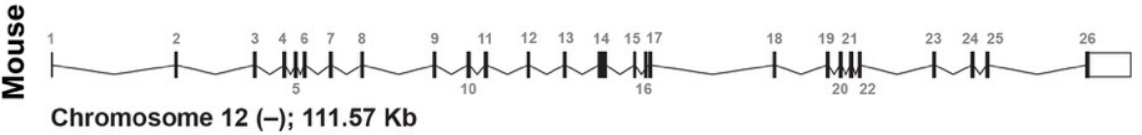

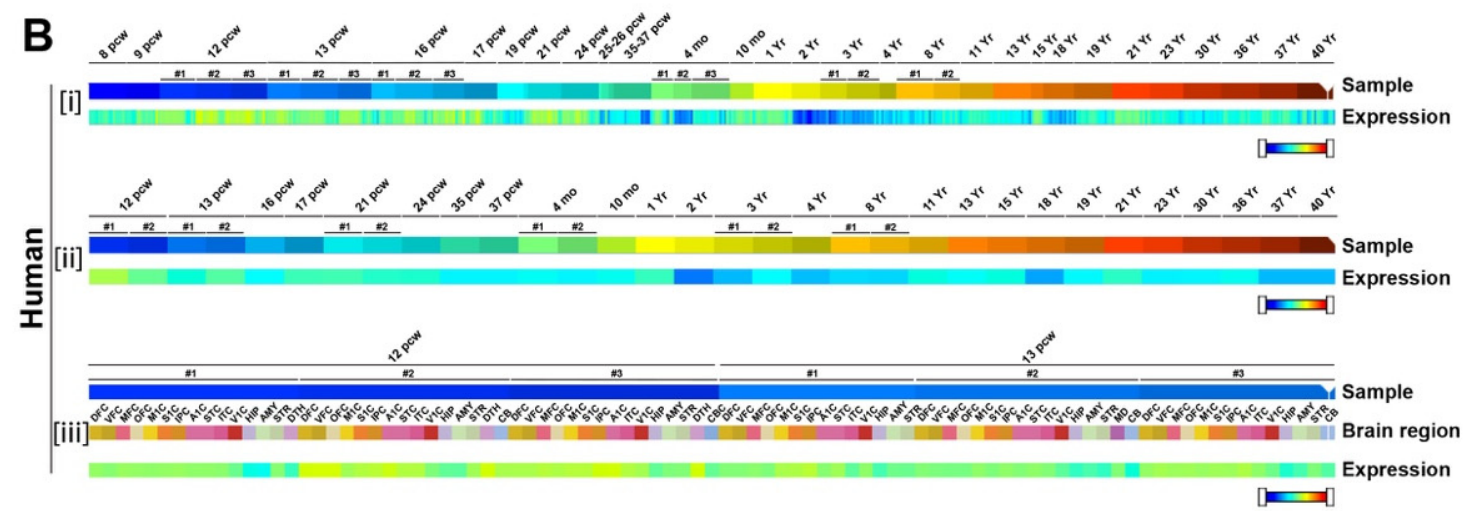

C AGTPBP1 PROTEIN

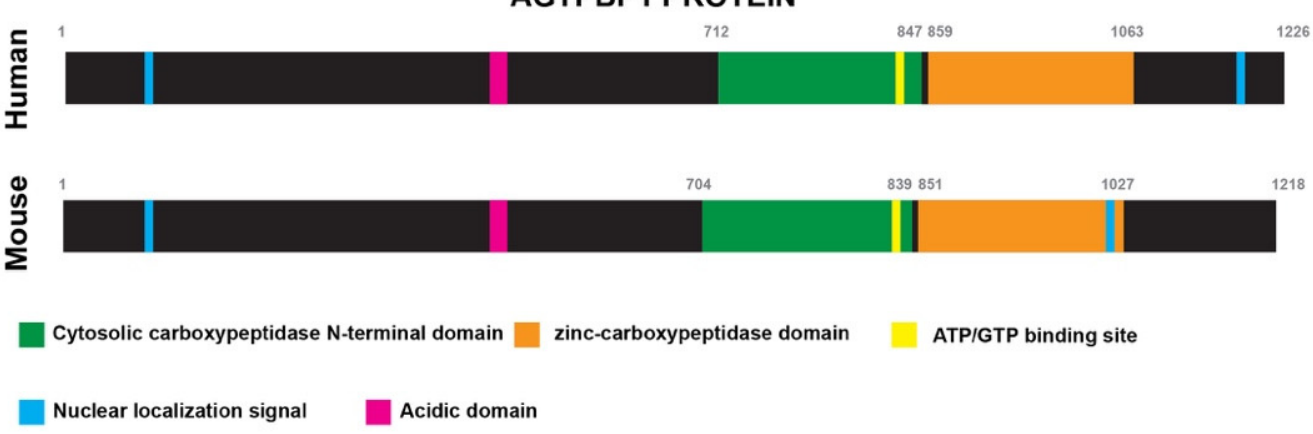

D

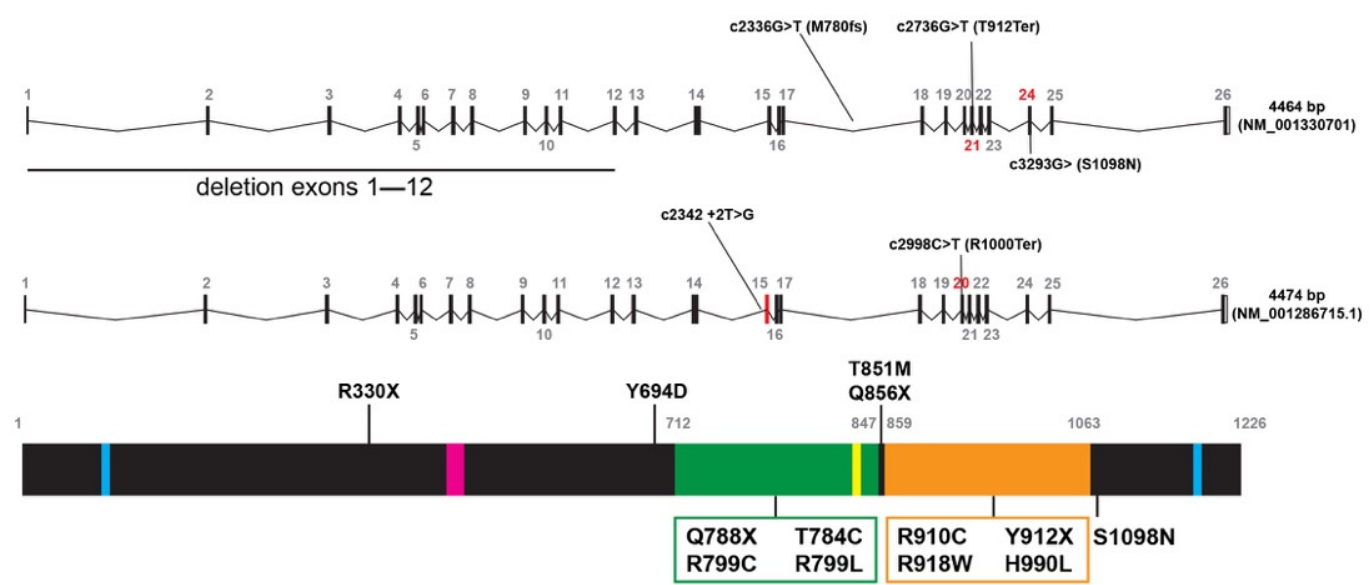

Figure 1. Genomic structure, organisation, expression and intron/exon distribution of AGTPBP1 in humans and in mice. (A) Genomic organisation of human AGTPBP1 and mouse AGTPBP1 loci. Figure assembled using current data from the Ensembl genome browser database (http:/ / www.ensembl.org/index.html) (accessed on 10 July 2021). Chromosomal location, chromosome strand (+ or -) used for transcription, and the size $(\mathrm{Kb})$ of the genomic stretches containing the AGTPBP1 locus are also indicated for each species. Exons (solid vertical boxes) are numbered. The open box indicates the alternatively spliced region of the exon. (B) Schematic representation of [i] overall expression of the hAGTPBP1 gene throughout 
development in all studied brain structures, [ii] the specific expression of the $\mathrm{h} A G T P B P 1$ gene in the cerebellum throughout development, and [iii] region-specific hAGTPBP1 gene expression at 12-13 pcw. (C) Schematic representation of the primary structure of the human and mouse AGTPBP1 proteins. The structural domains and their relative positions are indicated. (D) Schematic representation of the human AGTPBP1 gene structure and the encoded protein and the locations of variations found in patients with AGTPBP1 mutations. DFC: dorsolateral prefrontal cortex; VFC: ventrolateral prefrontal cortex; MFC: anterior (rostral) cingulate (medial prefrontal) cortex; OFC: orbital frontal cortex; M1C: primary motor cortex; S1C: primary somatosensory cortex; IPC: inferior parietal cortex; A1C: primary auditory cortex; STC: superior temporal cortex; ITC: inferolateral temporal cortex; V1C: primary visual cortex; HIP: hippocampus; AMY: amygdaloid complex; STR: striatum; DTH: dorsal thalamus; CB: cerebellum; CBC: cerebellar cortex. PWC: postconception weeks; MO: Months; Yr: Year.

\subsection{Expression Pattern}

$\mathrm{h} A G T P B P 1 \mathrm{mRNA}$ or protein is detectable in practically all human cells, tissues and organs tested. Of note, the mRNA and protein expression levels of hAGTPBP1 differ significantly depending on the specific organ and tissue.

According to the consensus dataset of the Human Protein Atlas database obtained based on transcriptomic analyses of human tissue and organs, the mRNA expression of $\mathrm{hAGTPBP1}$ is the highest in bone marrow (https://www.proteinatlas.org/ENSG00000 135049-AGTPBP1/tissue) (accessed on 10 July 2021) followed by many regions of the central nervous system, including the spinal cord, pons and medulla, corpus callosum, cerebellar cortex, hippocampal formation and olfactory region, among others. hAGTPBP1 mRNA expression is generally higher in the brain than in all other non-brain tissues. For example, low mRNA expression levels are detected in the ovary, liver, stomach, small intestine, lung, adrenal gland, spleen, and thymus, among other tissues. Similar distribution patterns of $\mathrm{mAGTPBP1}$ mRNA were found in mouse tissues [7,12]. In brain regions, $\mathrm{mAGTPBP1}$ is expressed preferably in differentiating neurons rather than in proliferating precursors/progenitors. [7].

Using the BrainSpan Developmental Transcriptome database, which contains data related to human gene expression in 16 specific brain structures obtained using RNA sequencing and exon microarray analysis of 42 brain samples spanning pre- and post-natal development, both the temporal and regional specificity of $h A G T P B P 1$ gene expression in the brain can be examined (https:/ / www.brainspan.org/rnaseq/searches? exact_match= false\&search_term =\%22NNA1\%22\&search_type=gene) (accessed on 10 July 2021). Regarding the temporal pattern of $\mathrm{h} A G T P B P 1$ expression, overall higher $\mathrm{h} A G T P B P 1$ gene expression is detected during embryonic development than during childhood and adulthood (Figure 1B, panel i), with the expression of the gene peaking at approximately 12-13 postconception weeks ( $\mathrm{pcw}$ ). In contrast, the lowest $\mathrm{h} A G T P B P 1$ gene transcription is found in brain samples from children (2-8 years old) (Figure 1B, panel i). A very similar expression pattern is found in the cerebellum and cerebellar cortex throughout development (Figure 1B, panel ii). With regards to regional-specific expression, in the specific time windows in which the hAGTPBP1 gene shows the highest transcription levels ( 12-13 pcw), the highest $\mathrm{h} A G T P B P 1$ gene expression levels are found in the prefrontal and frontal cortices and the dorsal thalamus, whereas the lowest levels are detected in the hippocampus, cerebellum and striatum (Figure 1B, panel iii).

\section{The AGTPBP1 Protein}

\subsection{Modular Domain Structure}

The hAGTPBP1 gene encodes a 1226-amino acids (aa) protein (https: / www.uniprot. org/uniprot/Q9UPW5) (accessed on 10 July 2021) containing a P-loop ATP/GTP-binding motif and a nucleotide-binding site. The primary structure of the hAGTPBP1 protein is a sequential, linearly organised modular configuration featuring conserved distribution of two well-defined domains: the cytosolic carboxypeptidase N-terminal domain (aa 712-847), which is highly conserved among M14D subfamily members [12,26], and the catalytic zinc- 
carboxypeptidase domain (aa 859-1063; Figure 1C). The ATP/GTP binding site is at aa 820-825, and an active catalytic site is found at position 970. Using cNLS mapper software (http://nls-mapper.iab.keio.ac.jp/cgi-bin/NLS_Mapper_form.cgi) (accessed on 10 July 2021), two bipartite nuclear localisation signals (NLSs) were predicted: a signal at the N-terminal region (aa 120-149) and a signal situated at the C-terminus (aa 1139-1165). In addition, other key residues directly related to the function of the protein were identified, including zinc-binding sites in the hAGTPBP1 protein (residues 920, 923 and 1017) [12]. Importantly, the hAGTPBP1 protein is highly evolutionarily conserved, sharing $\sim 72.5 \%$ identity with the AGTPBP1 protein in D. melanogaster and D. rerio and $87.2 \%$ identity with the AGTPBP1 protein in mice, supporting the notion that this gene, especially the catalytic domains, is highly conserved in metazoans [26-28]. The mAGTPBP1 gene encodes a 1218-aa protein (https: / / www.uniprot.org/uniprot/Q641K1) (accessed on 10 July 2021) that also contains a cytosolic carboxypeptidase N-terminal domain (aa 704-839; Figure 1C) and a zinc-carboxypeptidase domain (aa 851-1027; Figure 1C). The ATP/GTP binding site is at aa 810-817, and the active site is located at residue 962. Whereas mutation of the ATP/GTP binding site has no effect in vivo, preservation of a functional zinc-binding domain is essential for neuronal survival $[14,29,30]$. Zinc-binding sites in the mAGTPBP1 protein are found at residues 912, 915 and 1009. The NLSs are positioned at both the N-terminal domain (aa 144-151) and C-terminal domain (aa 996-1016) [9].

\subsection{Expression Pattern}

hAGTPBP1 protein expression level data have revealed that the protein is expressed at the highest level in the testis (https: / / www.proteinatlas.org/ENSG00000135049-AGTPBP1 / tissue) (accessed on 10 July 2021). Moderate protein expression levels are also observed in human brain regions, such as the cerebral cortex and cerebellum, and other organs, including the lung, stomach, kidney, pancreas, and muscle.

At the cellular level, the AGTPBP1 protein is detected both in the cytoplasm, mainly in vesicles and mitochondria, and in the nucleus, particularly in the nucleolus (https: / / www.proteinatlas.org/ENSG00000135049-AGTPBP1/cell) (accessed on 10 July 2021), as reported for mAGTPBP1 $[7,18,26]$.

\subsection{Role of the AGTPBP1 Protein}

Microtubules are major components of the cytoskeleton composed of $\alpha$ - and $\beta$-tubulin heterodimer subunits that polymerise to form tubular and polar structures [31]. Both tubulin subunits are subject to certain PTMs, including the tyrosination/detyrosination and polyglutamylation of $\alpha$-tubulin [32]. The tyrosination/detyrosination cycle involves the reversible removal and re-addition of a tyrosine residue at the C-terminus of $\alpha$-tubulin. Two enzymes participate in this cycle: tubulin tyrosine ligase (TTL) and tubulin carboxypeptidase (TubCP). The latter cleaves the $\mathrm{C}$-terminal tyrosine residue of $\alpha$-tubulin, resulting in Glu-tubulin. The tyrosine residue can be re-added by TTL, forming Tyr-tubulin again. Another variant of non-tyrosinable $\alpha$-tubulin ( $\Delta 2$-tubulin) that lacks the Glu C-terminal residue was defined.

Several years ago, the enzymes catalysing tubulin PTMs were fully characterised [33]. Cytosolic carboxypeptidase (CCP) subfamily comprises six members (CCP1-CCP6), [12,13]. CCP enzymes process amino acid residues from the C-terminus $[15,34]$ and are also involved in reversing polyglutamylation catalysed by polyglutamylases from the tubulintyrosine ligase-like family and in removing glutamate residues from the C-terminus, thus transforming $\alpha$-tubulin into non-tyrosinable $\Delta 2$-tubulin [15] (Figure 2A,B). In particular, CCP1, encoded by the AGTPBP1 gene, acts as a tubulin deglutamylase, generating $\triangle 2$-tubulin from Glu-tubulin, and also counteracts the tubulin-tyrosine ligase-like mediated reaction and then shortens the long glutamate chains generated by polyglutamylases $[15,16,35]$. In addition, myosin light chain kinase and telokin proteins were also identified as substrates for CCP1 [15] (Figure 2C). 
A

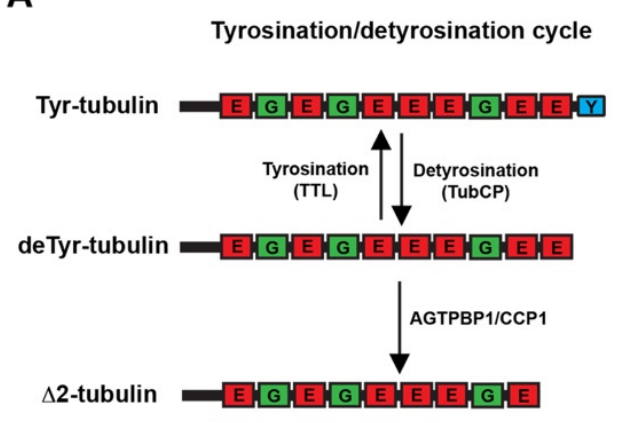

C

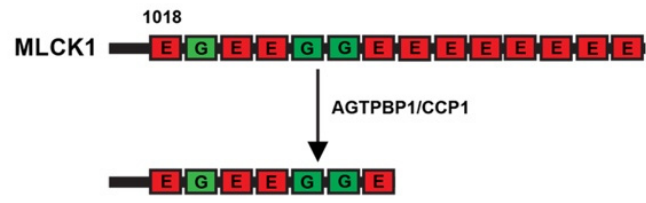

B

Polyglutamylation/deglutamylation cycle
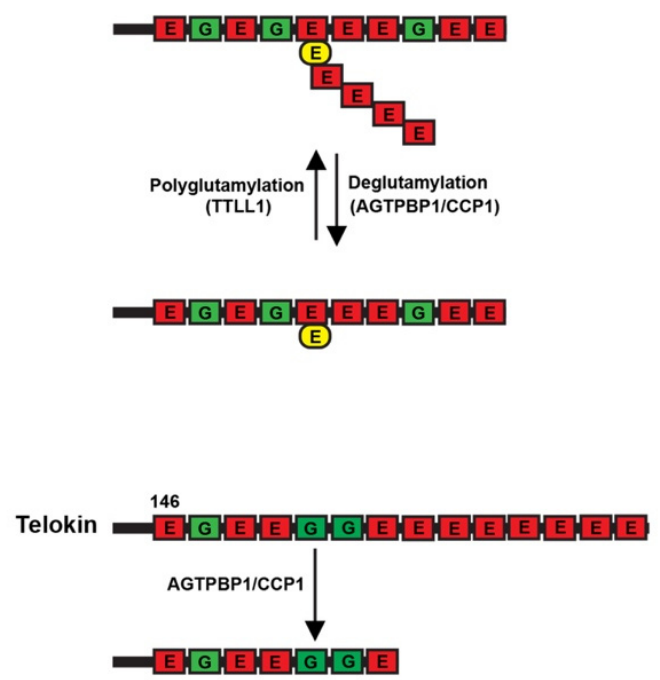

Figure 2. AGTPBP1/CCP1-mediated tubulin posttranslational modifications. (A,B) Schematic representation of the two AGTPBP1/CCP1-mediated tubulin posttranslational modifications. (C) Schematic representation of the deglutamylation of MLCK1 (left) and telokin (right) catalysed by AGTPBP1/CCP1. The numbers indicate the amino acid residues. MLCK1: Myosin light chain kinase 1. TTL: Tubulin Tyrosine Ligase; TTLL1: Tubulin Tyrosine Ligase-Like 1; TubCP: Tubulin Carboxypeptidase. Scheme is a modification of [15].

Although AGTPBP1 contains two NLSs [9] and is expressed in the nucleus [7], its contribution to nuclear physiology remains uncertain; however, it was suggested that this protein may be involved in chromatin remodelling [7].

\section{AGTPBP1 Mutation-Related Childhood-Onset Neurodegeneration with Cerebellar Atrophy (CONDCA)}

Shashi and colleagues (2018) identified biallelic variants in the AGTPBP1 gene in patients suffering from an infantile-onset neurodevelopmental disorder known as childhoodonset neurodegeneration with cerebellar atrophy (CONDCA) [1]. At the time this review was written, a total of 18 individuals from 15 different families were reported to carry damaging CONDCA-associated, biallelic, loss-of-function variants of the AGTPBP1 gene (Table 1). The affected individuals, most of them unrelated, were born from both consanguineously related and unrelated parents, and the disease appeared to equally affect both males and females (Table 2).

Complete exome sequencing analysis of CONDCA patient samples revealed rare allelic variants of the AGTPBP1 gene, including (i) missense mutations predicted to result in single aa substitutions; (ii) a canonical splice-site change causing disturbance of the open reading frame; (iii) de novo heterozygous stop-gain variants predicted to generate a premature stop codon; (iv) an intronic splice-site change predicted to lead to the in-frame absence of 29 highly conserved aa; and (v) a 12-exon-long genomic deletion (Table 1; Figure 1D) [1-4]. The majority of these variants affect the highly conserved $\mathrm{N}$-terminal regions and zinc-carboxypeptidase protein motifs (Figure 1D). As a consequence, the function of the AGTPBP1 protein is abrogated due to a reduction in mRNA transcription, nonsense-mediated mRNA decay, early protein truncation and protein misfolding into a structure that is highly susceptible to proteasome-dependent proteolysis [1]. 
Table 1. Identified biallelic variants in the AGTPBP1 gene. M: Male F: Female. * means substitution.

\begin{tabular}{|c|c|c|c|c|}
\hline $\begin{array}{l}\text { Patient (Age; Sex; } \\
\text { Consanguinity) }\end{array}$ & Allelic Variant & Consequence & Region Affected & Reference \\
\hline \multirow[t]{2}{*}{ 2-year-old; F; NO } & $\begin{array}{l}\text { NM_001330701 } \\
\text { c.2336-1G>T }\end{array}$ & $\begin{array}{l}\text { Transversion in intron } 17 . \\
\text { Results in a splice site } \\
\text { aberration, a frameshift and } \\
\text { premature termination } \\
\text { (M780fs) }\end{array}$ & $\begin{array}{l}\text { Cytosolic carboxypeptidase } \\
\text { N-terminal domain }\end{array}$ & {$[1]$} \\
\hline & $\begin{array}{l}\text { NM_001330701 } \\
\text { c.2736delC }\end{array}$ & $\begin{array}{l}\text { Deletion in exon 21. Results in } \\
\text { a frameshift and premature } \\
\text { termination (T912Ter) }\end{array}$ & $\begin{array}{l}\text { Zinc-carboxypeptidase } \\
\text { domain }\end{array}$ & {$[1]$} \\
\hline 12-month-old; M; YES & $\begin{array}{l}\text { NM_001330701 } \\
\text { c. } 2752 C>T\end{array}$ & $\begin{array}{l}\text { Transition in exon } 21 . \text { Results } \\
\text { in R918W substitution }\end{array}$ & $\begin{array}{c}\text { Zinc-carboxypeptidase } \\
\text { domain }\end{array}$ & {$[1]$} \\
\hline 7-month-old; M; YES & - & Deletion of exons 1 to 12 & Non-defined & [1] \\
\hline Not available & $\begin{array}{l}\text { NM_015239.2 } \\
\text { c. } 2632 \mathrm{C}>\mathrm{T}\end{array}$ & $\begin{array}{l}\text { Cerebellar hypoplasia and } \\
\text { lower motor neuron } \\
\text { degeneration. Results in } \\
\text { R878W substitution }\end{array}$ & $\begin{array}{l}\text { Zinc-carboxypeptidase } \\
\text { domain }\end{array}$ & {$[4]$} \\
\hline \multirow[t]{2}{*}{ 4-year-old; M; NO } & $\begin{array}{l}\text { NM_001286715 } \\
\text { c. } 2351 \mathrm{~A}>\mathrm{G}\end{array}$ & Results in a T784C substitution & Non-defined & \multirow[t]{2}{*}{ [2] } \\
\hline & $\begin{array}{l}\text { NM_001286715 } \\
\text { c. } 2998 \mathrm{C}>\mathrm{T}\end{array}$ & $\begin{array}{l}\text { Results in a frameshift and } \\
\text { premature termination } \\
\text { (R1000Ter) }\end{array}$ & $\begin{array}{l}\text { Zinc-carboxypeptidase } \\
\text { domain }\end{array}$ & \\
\hline 15-month-old; M; YES & $\begin{array}{l}\text { NM_001286715 } \\
\text { c. } 2342 \mathrm{C}>\mathrm{T}+2 \mathrm{~T}>\mathrm{G}\end{array}$ & $\begin{array}{l}\text { Skips exon } 15 \text { (loss of } 29 \text { highly } \\
\text { conserved aa) }\end{array}$ & $\begin{array}{l}\text { Non-defined modular } \\
\text { domain }\end{array}$ & [2] \\
\hline 5-year-old; F; NO & $\begin{array}{c}\text { NM_001330701 } \\
\text { c.2752C >T } \\
\text { NM_001330701 } \\
\text { c.2080T>G }\end{array}$ & $\begin{array}{l}\text { Transition in exon 21. Results } \\
\text { in R918W substitution } \\
\text { Transversion in exon } 15 . \\
\text { Results in a Y694D substitution }\end{array}$ & $\begin{array}{c}\text { Zinc-carboxypeptidase } \\
\text { domain } \\
\text { Non-defined }\end{array}$ & {$[1]$} \\
\hline 16-month-old; F; YES & $\begin{array}{l}\text { NM_001330701 } \\
\text { c. } 2566 C>T\end{array}$ & $\begin{array}{l}\text { Homozygous transition in } \\
\text { exon 19. Results in a Q856* }\end{array}$ & Non-defined & [1] \\
\hline 8-year-old; M; YES & $\begin{array}{l}\text { NM_001330701 } \\
\text { c. } 2395 \mathrm{C}>\mathrm{T}\end{array}$ & Results in a R799C substitution & $\begin{array}{l}\text { Cytosolic carboxypeptidase } \\
\text { N-terminal domain }\end{array}$ & {$[1]$} \\
\hline 8-year-old; M; YES & $\begin{array}{l}\text { NM_001330701 } \\
\text { c. } 2566 C>T\end{array}$ & Results in a P799C substitution & $\begin{array}{l}\text { Cytosolic carboxypeptidase } \\
\text { N-terminal domain }\end{array}$ & [1] \\
\hline 7-month-old; M; YES & $\begin{array}{l}\text { NM_001330701 } \\
\text { c.2396G }>\text { T }\end{array}$ & Results in a P799L substitution & $\begin{array}{l}\text { Cytosolic carboxypeptidase } \\
\text { N-terminal domain }\end{array}$ & {$[3]$} \\
\hline 2-year-old; M; YES & $\begin{array}{l}\text { NM_001330701 } \\
\text { c.2396G > T }\end{array}$ & Results in a P799L substitution & $\begin{array}{l}\text { Cytosolic carboxypeptidase } \\
\text { N-terminal domain }\end{array}$ & {$[3]$} \\
\hline 20-month-old; F; NO & $\begin{array}{l}\text { NM_001330701 } \\
\text { c.988C > T }\end{array}$ & $\begin{array}{l}\text { Results in a R330* } \\
\text { Results in a Y912X substitution }\end{array}$ & $\begin{array}{c}\text { Non-defined } \\
\text { Zinc-carboxypeptidase } \\
\text { domain }\end{array}$ & {$[1]$} \\
\hline $\begin{array}{l}\text { 8-year-old; M; YES and } \\
\text { 5-year-old; F; YES }\end{array}$ & $\begin{array}{l}\text { NM_001330701 } \\
\text { c. } 2728 \mathrm{C}>\mathrm{T}\end{array}$ & Results in a R910C substitution & $\begin{array}{l}\text { Zinc-carboxypeptidase } \\
\text { domain }\end{array}$ & {$[1]$} \\
\hline 3 infant sibs; YES & $\begin{array}{l}\text { NM_001330701 } \\
\text { c. } 2362 C>T\end{array}$ & $\begin{array}{l}\text { Transition in exon 18. Results } \\
\text { in a Q788* }\end{array}$ & $\begin{array}{l}\text { Cytosolic carboxypeptidase } \\
\text { N-terminal domain }\end{array}$ & {$[1]$} \\
\hline \multirow[t]{2}{*}{ 14-year-old; M; NO } & $\begin{array}{l}\text { NM_001330701 } \\
\text { c. } 2552 C>T\end{array}$ & $\begin{array}{c}\text { Transition in exon } 19, \text { resulting } \\
\text { in a T851M substitution }\end{array}$ & Non-defined & [1] \\
\hline & $\begin{array}{l}\text { NM_001330701 } \\
\text { c. } 2969 A>T\end{array}$ & $\begin{array}{c}\text { transversion in exon } 22, \\
\text { resulting in a H990L } \\
\text { substitution }\end{array}$ & $\begin{array}{l}\text { Zinc-carboxypeptidase } \\
\text { domain }\end{array}$ & \\
\hline 21-month-old; M; YES & $\begin{array}{l}\text { NM_001330701 } \\
\text { c.3293G >A }\end{array}$ & $\begin{array}{l}\text { Mutation in exon } 24, \text { resulting } \\
\text { in a S1098N substitution }\end{array}$ & $3^{\prime}$ end domain & {$[36]$} \\
\hline 17-year-old; F; YES & $\begin{array}{l}\text { NM_001330701 } \\
\text { c.3293G >A }\end{array}$ & $\begin{array}{l}\text { Mutation in exon 24, resulting } \\
\text { in an S1098N substitution }\end{array}$ & $3^{\prime}$ end domain & [36] \\
\hline
\end{tabular}


Table 2. Clinical findings reported for patients harboring AGTPBP1-mutated gene.

\begin{tabular}{|c|c|}
\hline Feature & Data from $[1-4,36]$ \\
\hline Onset & Birth to 20 months \\
\hline \multirow{2}{*}{ Gender } & $10 \mathrm{~F}, 9 \mathrm{M}$ \\
\hline & Not available (1) \\
\hline \multirow{2}{*}{ Consanguinity } & $14 / 19$ \\
\hline & Not available (1) \\
\hline Progressive degenerative course & $19 / 20$ \\
\hline \multirow{2}{*}{ Microcephaly } & $11 / 20$ \\
\hline & Not available (1) \\
\hline Motor delay & $20 / 20$ \\
\hline \multirow{2}{*}{ Hypotonia } & $19 / 20$ \\
\hline & Not available (1) \\
\hline \multirow{4}{*}{ Muscle weakness } & $16 / 18$ \\
\hline & Not available (2) \\
\hline & Tetraparesis/plegia (8) \\
\hline & Lower limb (2) \\
\hline \multirow[t]{3}{*}{ Muscle weakness pattern } & $\operatorname{Neck}(3)$ \\
\hline & Diaphragm/intercostal (4) \\
\hline & Not specified (8) \\
\hline Muscle atrophy & $9 / 18$ \\
\hline \multirow{3}{*}{ Tongue fasciculations } & $7 / 20$ \\
\hline & Not available $(13 / 20)$ \\
\hline & Low or absent $(10 / 20)$ \\
\hline \multirow{3}{*}{ Tendon reflexes } & Normal $(3 / 20)$ \\
\hline & Increased (6/29) \\
\hline & Not available (1) \\
\hline \multirow{2}{*}{ Ataxia } & Yes (6) \\
\hline & Not available (12) \\
\hline \multirow{2}{*}{ Dystonia } & $5 / 20$ \\
\hline & Not available (1) \\
\hline \multirow{2}{*}{ Spasticity } & $7 / 20$ \\
\hline & Not available (3/18) \\
\hline \multirow{2}{*}{ Respiratory distress } & $9 / 20$ \\
\hline & Not available (1) \\
\hline \multirow{3}{*}{ Feeding difficulties } & $13 / 20$ \\
\hline & Not available (1) \\
\hline & Detected $(12 / 20)$ \\
\hline \multirow[t]{3}{*}{ Eye movement abnormalities } & Not detected $(6 / 20)$ \\
\hline & Not available $(2 / 20)$ \\
\hline & Impaired $(1 / 20)$ \\
\hline \multirow[t]{2}{*}{ Hearing } & Normal $(5 / 20)$ \\
\hline & Not available $(14 / 20)$ \\
\hline \multirow{3}{*}{ Cognitive delay } & $17 / 20$ \\
\hline & Not available $(3 / 20)$ \\
\hline & Cerebellar atrophy $(18 / 20)$ \\
\hline \multirow{4}{*}{ Brain MRI } & Dysplastic corpus callosum $(6 / 20)$ \\
\hline & Small pons $(1 / 20)$ \\
\hline & Enlarged CSF spaces $(1 / 20)$ \\
\hline & Motor neuropathy $(2 / 20)$ \\
\hline \multirow{3}{*}{ Nerve conduction studies } & Axonal motor neuropathy $(5 / 20)$ \\
\hline & Normal $(1 / 18)$ \\
\hline & Not available $(12 / 20)$ \\
\hline \multirow{4}{*}{ Electromyography } & Denervation $(5 / 20)$ \\
\hline & Neurogenic $(2 / 20)$ \\
\hline & Normal $(1 / 20)$ \\
\hline & Not available $(12 / 20)$ \\
\hline
\end{tabular}

The clinical findings of patients with AGTPBP1 mutations are summarised in Table 2. Overall, the patients display early-onset developmental delays (between birth and 20 months 
of age) with a progressive degenerative course, mainly characterised by hypotonia and generalised muscle weakness, frequently causing tetraparesis. Brain MRI revealed detected cerebellar atrophy with respect to non-affected, control individuals (Figure 3A,B). Other brain alterations, such as microcephaly or dysplastic corpus callosum, were also frequently detected. Alterations in tendon reflexes were observed in almost all individuals. Muscle atrophy was found in half of the patients (Figure 3C,D), and other regularly detected clinical manifestations included feeding problems, eye movement abnormalities, respiratory insufficiency, spasticity, tongue fasciculations and dystonia. Other clinical features, such as bilateral hearing loss and hand tremors, were sporadically detected.
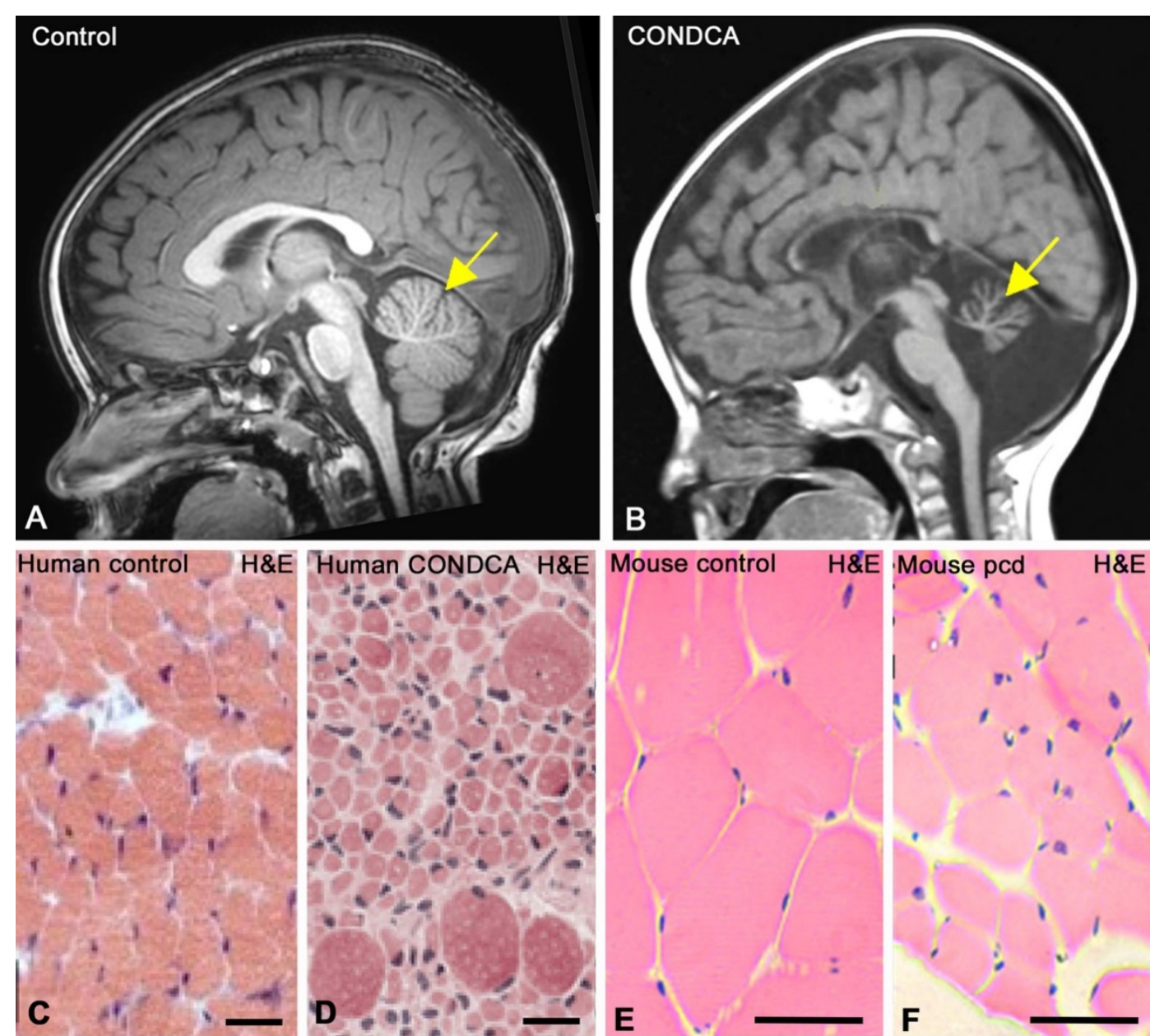

Figure 3. Cranial magnetic resonance imaging (MRI) of a control (A) and a CONDCA patient (B). Whereas the 20-month-old female healthy control patient (A) shows a typical well-developed cerebellum (yellow arrow), severe cerebellar atrophy (yellow arrow) is observed in the 24-month-old female CONDCA patient (B). (A) Courtesy of Dr. Ana Canga, "Hospital Universitario Marqués de Valdecilla", Santander (Spain). (B) Adapted from [3]. Copyright 2019 American Journal of Medical Genetics. (C,D) Haematoxylin-eosin (H\&E)-stained skeletal muscle tissue biopsies at 7 months of age from healthy control (C) and CONDCA patients (D). Note the fibre atrophy with a few interspersed hypertrophic fibres in the muscle tissue of the patient. Scale bars: $50 \mu \mathrm{m}$. Adapted with permission from [1]. Copyright 2018 The EMBO Journal. (E,F) Haematoxylin-eosin (E,H)-stained skeletal muscle tissue cross-sections from control (E) and pcd (F) mice. Note the muscle atrophy and the notable reduction in muscle fibre size in the $p c d$ mouse. Scale bars: $30 \mu \mathrm{m}$. Adapted with permission from [37]. Copyright 2018 Journal of Tissue Engineering and Regenerative Medicine.

Electrophysiological recordings revealed motor neuropathy affecting the lower limbs and arms. In particular, electromyography studies have detected signs of denervation causing muscle atrophy in proximal and distal muscles, including the tibialis anterior and posterior deltoid, suggesting degeneration of both peripheral nerve motor fibres and spinal 
cord $\alpha$-motor neurons. In contrast, sensory nerve action potentials seemed to be unaffected, suggesting that the neuropathy was mainly of motor origin. Progressive advancement of the neurological disorders resulted in the death of 7 patients out of the 18 individuals carrying damaging variants of the AGTPBP1 gene.

It is relevant to mention that in a very recently published paper, two members of a consanguineous family harbouring a novel homozygous variant (c.3293G>A) at the $3^{\prime}$ end of the AGTPBP1 gene (Figure 1D) showed no signs of cerebellar atrophy [36]. Further analysis is needed to examine whether only AGTPBP1 mutations affecting the catalytic domains of the protein are directly associated with cerebellar atrophy.

At the cellular level, deleterious accumulation of polyglutamylated tubulin was detected in biopsies taken from the quadriceps muscles of CONDCA patients with AGTPBP1 mutations [1]. Additionally, this hyperglutamylation is directly related to neurodegeneration in mice and humans, most likely due to deficiency in microtubule-based axonal transport [38].

Interestingly, a recent study has identified the $A G T P B P 1$ gene as being the most significant gene coexpressed with the amyotrophic lateral sclerosis (ALS)-linked gene C90RF72 and revealed a positive correlation between the expression of their respective mRNAs [39]. These findings suggest that AGTPBP1 is an interacting partner of C90rf72 that contributes to the regulation of important neuronal functions [39]. This raises questions regarding the potential role of AGTPBP1 in other human neurological disorders.

\section{The pcd Mouse as an Animal Model for Studying AGTPBP1 Mutation-Related CONDCA}

More than 40 years ago, a spontaneous recessive mutation that causes early cerebellar ataxia and is associated with rapid degeneration of cerebellar PCs was identified [5]. This mutation was subsequently called pcd [5]. To date, damaging mutations in AGTPBP1, including spontaneous mutant variants, chemically induced variants, transgenic alleles and conditional knockout, were reported (Table 3 ). The most severe pathological alleles are

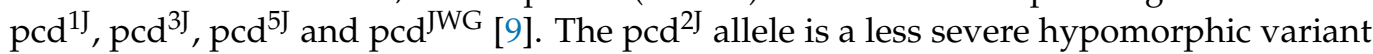
that causes a mild phenotype and the development of ataxia much later than other pcd mutants but not thalamic degeneration (Table 3). A recently generated AGTPBP1 KO mouse model in which exons 21-22 are deleted [40], exhibits similar pathological features as those reported for pcd1J, $\mathrm{pcd}^{3 \mathrm{~J}}$ or $\mathrm{pcd}^{5 \mathrm{~J}}$ (Table 3).

Loss of function of the AGTPBP1 gene was subsequently identified as being responsible for the $p c d$ phenotype $[7,10]$. pcd mice have a smaller body and lower body weight than their wild-type counterparts $[35,40]$. In addition to PC degeneration, the pcd mutation leads to postnatal degeneration of other distinct neuronal populations, including MCs in the OB [20], photoreceptors in the retina [6], a certain subpopulation of thalamic neurons [21] and peripheral nerve and spinal motor neurons [1].

Interestingly, the time course of degeneration of affected neuronal populations in pcd mice markedly differs among them, making this animal model highly appropriate for studying different neuronal degenerative processes caused by the same mutation. Degeneration of photoreceptors is slow and takes approximately one year [6,41] whereas the death of thalamic neurons and MCs takes up to 6 and 4 months, respectively [20,21]. In contrast, degeneration of PCs occurs extremely quickly, is severe and occurs between 3 and 4 weeks of age. In fact, almost all PCs are eliminated at a well-defined time point, approximately by 1 month after birth. To date, no clear findings supporting marked variations in these neurodegenerative processes exist. Since most $p c d$ mice survive, secondary neuronal death and remodelling of neuronal networks, as consequences of primary neurodegeneration, were reported in the affected regions.

Interestingly, cerebellar atrophy is one of the earliest signs of the disease manifested in CONDCA patients, which resembles the early PC degeneration and the cerebellar atrophy showed by $p c d$ mice. Nevertheless, although the correspondence of other clinical findings between CONDCA patients and $p c d$ mice is established (Table 4) it still remains unknown if the developmental course of the pathologies is comparable in both groups. With the 
currently available data, the assumption of similar developmental phases of the disease between CONDCA patients and $p c d$ mice cannot be yet established.

Table 3. Summary of AGTPBP1 reported mutant alleles. ENU: N-ethyl-N-nitrosourea.

\begin{tabular}{|c|c|c|c|}
\hline Allele Name Mutation & Mutation & Clinical Features & Genetic Mutation in AGTPBP1 \\
\hline Agtpbp $1^{\text {pcd-1J }}$ & Spontaneous & $\begin{array}{l}\text { Reduced body size; Ataxia; cerebellar atrophy; } \\
\text { postnatal degeneration of thalamic neurons, PCs, } \\
\text { MCs and retinal photoreceptors; male infertility; } \\
\text { female partial fertility. }\end{array}$ & $\begin{array}{c}\text { Unknown (possibly in regulatory } \\
\text { region) }\end{array}$ \\
\hline Agtpbp $1^{p c d-2 J}$ & Spontaneous & Hylomorphic allele with reduced & $\begin{array}{c}\text { Insertion }(\sim 7.8 \mathrm{~Kb}) \text { between exons } \\
14-15\end{array}$ \\
\hline Agtpbp $1^{\text {pcd-3J }}$ & Spontaneous & $\begin{array}{c}\text { Reduced body size; Ataxia; Cerebellar atrophy; } \\
\text { postnatal degeneration of thalamic neurons, PCs, } \\
\text { MCs and photoreceptors; male infertility; female } \\
\text { partial fertility; Reduced number of } \\
\text { antral follicles. }\end{array}$ & $\begin{array}{l}\text { Deletion }(\sim 12.2 \mathrm{~Kb}) \text { between } \\
\quad \text { intron } 5 \text { and exon } 8\end{array}$ \\
\hline Agtpbp $1^{p c d-4 J}$ & $\begin{array}{l}\text { ENU-induced } \\
\text { mutagenesis }\end{array}$ & Ataxia; degeneration of PCs & Unknown \\
\hline Agtpbp $1^{\text {pcd-5J }}$ & Spontaneous & Ataxia; Degeneration of PCs and MCs & $\begin{array}{l}\text { Insertion of an aspartic acid } \\
\text { residue (D775) in exon } 18\end{array}$ \\
\hline Agtpbp $1^{\text {pcd-6J }}$ & $\begin{array}{l}\text { ENU-induced } \\
\text { mutagenesis }\end{array}$ & $\begin{array}{c}\text { Ataxia; cerebellar and testicular atrophy; } \\
\text { postnatal degeneration of PCs, MCs and } \\
\text { photoreceptors; decreased skeletal muscle fiber } \\
\text { size; male infertility. }\end{array}$ & Unknown \\
\hline Agtpbp $1^{\text {pcd-7J }}$ & Spontaneous & $\begin{array}{l}\text { Ataxia; postnatal degeneration of PCs; enlarged } \\
\text { hippocampus; abnormal hearing } \\
\text { Affectation of behavior; low size body; }\end{array}$ & Unknown \\
\hline Agtpbp $1^{\text {pcd-8J }}$ & Spontaneous & $\begin{array}{c}\text { Alteration of nervous system development, } \\
\text { reproductive, and vision. }\end{array}$ & Unknown \\
\hline Agtpbp $1^{\text {pcd-9J }}$ & Spontaneous & $\begin{array}{l}\text { Ataxia, but has a slightly later onset than that } \\
\text { caused by the original } p c d \text { allele. }\end{array}$ & Unknown \\
\hline Agtpbp1 $1^{\text {pcd-Tg(Dhfr)1jwg }}$ & Transgene insertion & $\begin{array}{l}\text { Ataxia; degeneration of PCs, MCs and } \\
\text { photoreceptor cells; some male infertility, female } \\
\text { partial fertility; degeneration of sperm }\end{array}$ & Random gene disruption \\
\hline Agtpbp $1^{\text {Drunk }}$ & Mutagenesis & $\begin{array}{l}\text { Degeneration of Purkinje cells and } \\
\text { photoreceptor cells; Male infertility }\end{array}$ & Unknown \\
\hline Agtpbp1 Rio & Mutagenesis & Tremor and abnormal sperm & Unknown \\
\hline Agtpbp $1^{\text {babe }}$ & $\begin{array}{l}\text { ENU-induced } \\
\text { mutagenesis }\end{array}$ & Ataxia; paraparesis & $\begin{array}{l}\text { P804 arginine to a termination } \\
\text { codon }\end{array}$ \\
\hline Agtpbp $1^{\text {pcd-Btlr }}$ & $\begin{array}{l}\text { ENU-induced } \\
\text { mutagenesis }\end{array}$ & $\begin{array}{l}\text { Ataxia; degeneration of PCs, MCs and } \\
\text { photoreceptor cells; male infertility, } \\
\text { oligozoospermia and teratozoospermia }\end{array}$ & $\begin{array}{l}\text { a T-to-A transversion in the donor } \\
\text { splice site of intron } 11\end{array}$ \\
\hline Agtpbp1 $1^{\text {pcd-m2Btr }}$ & $\begin{array}{l}\text { ENU-induced } \\
\text { mutagenesis }\end{array}$ & $\begin{array}{c}\text { Tremors; decreased body size; reduced activated } \\
\text { sperm motility }\end{array}$ & $\begin{array}{c}\text { an A to } G \text { transition; destroys the } \\
\text { acceptor splice site of intron } 7 \text { of } \\
\text { the gene }\end{array}$ \\
\hline Agtpbp $1^{\text {pcd-Sid }}$ & Spontaneous & Reduced body size; Ataxia; Cerebellar atrophy. & Deletion of exon 7 \\
\hline Agtpbp1 Gt(IST13517F11)Tigm & Gene trapped allele & one ES cell; unclassified & $\begin{array}{c}\text { Chr13:59477801-59478055 bp } \\
(-) ; \text { Chr13:59477801-59477979 bp (-) }\end{array}$ \\
\hline Agtpbp1 $1^{\mathrm{Gt}(\mathrm{OST} 186151) \text { Lex }}$ & Gene trapped allele & Lex-1 (ES Cell) & Chr13:59531904-59544452 bp (-) \\
\hline Agtpbp1 $1^{\mathrm{Gt}(\mathrm{OST} 188387) \text { Lex }}$ & Gene trapped allele & Lex-1 (ES Cell) & Chr13:59531902-59533237 bp (-) \\
\hline Agtpbp1 Gt(OST252171)Lex & Gene trapped allele & Lex-1 (ES Cell) & Chr13:59531904-59544452 bp (-) \\
\hline Agtpbp1 ${ }^{\mathrm{Gt}(\mathrm{OST} 300426) \mathrm{Lex}}$ & Gene trapped allele & Lex-1 (ES Cell) & Chr13:59531904-59544452 bp (-) \\
\hline Agtpbp1 Gt(OST300428)Lex & Gene trapped allele & Lex-1 (ES Cell) & Chr13:59536248-59536374 bp (-) \\
\hline Agtpbp1 ${ }^{\mathrm{Gt}(\mathrm{OST} 301743) \operatorname{Lex}}$ & Gene trapped allele & Lex-1 (ES Cell) & Chr13:59531913-59536374 bp (-) \\
\hline$p c d^{\mathrm{KO}}$ & Knock-out & $\begin{array}{l}\text { Ataxia; cerebellar atrophy, postnatal } \\
\text { degeneration of PCs and photoreceptors. }\end{array}$ & Deletion of exons 21 and 22 \\
\hline
\end{tabular}

In summary, the $p c d$ mouse is a suitable animal model for studying ataxia and cerebellar atrophy with genetic, clinical and histopathological characteristics similar to those of human CONDCA patients (Table 4). The following sections describe in detail the neuropathological signs and mechanisms of neurological dysfunction in $p c d$ mice.

\subsection{Degeneration in the Cerebellum}

One of the main phenotypic hallmarks of the pcd mutation in mice is early-onset cerebellar atrophy, which is mainly associated with drastic and premature primary degen- 
eration of PCs $[19,40]$, starting in the vermis and progressively advancing to the cerebellar hemispheres [42]. As degeneration proceeds, other cerebellar neuronal populations, such as granule cells and neurons of the inferior olivary complex and deep cerebellar nuclei (DCN), subsequently degenerate. However, this secondary degeneration process is much slower, taking approximately one year, probably as a consequence of primary PC death [9]. Consequently, there is an additional thinning of the molecular and granule cell layers with the subsequent worsening of the cerebellar atrophy $[43,44]$.

Table 4. Comparison of pathological findings between CONDCA patients and the pcd mutant mouse. N.E: Not examined.

\begin{tabular}{ccc}
\hline Physiopathological Feature & CONDCA Patients & $p c d$ Mice \\
\hline Early-onset & YES & YES \\
Progressive degenerative course & YES & YES \\
Microcephaly & YES & YES \\
Motor delay & YES & YES \\
Hypotonia & YES & N.E \\
Muscle weakness & YES & YES \\
Muscle atrophy & YES & YES \\
Tongue fasciculations & Frequent & N.E \\
Alteration of tendon reflexes & Frequent & N.E \\
Ataxia & Frequent & YES \\
Dystonia & Frequent & N.E \\
Spasticity & Frequent & N.E \\
Respiratory distress & Frequent & N.E \\
Feeding difficulties & Frequent & YES \\
Eye movement abnormalities & Frequent & N.E \\
Defective hearing & Occasional & YES \\
Cognitive delay & YES & YES \\
Denervation & Frequent & YES \\
Olfactory dysfunction & Frequent & YES \\
Visual deficiency & N.E & YES \\
Defective sperm & N.E & YES \\
Motor and axonal motor neuropathy & N.E & YES \\
\hline
\end{tabular}

At the molecular level, analysis of the transcriptional signature in the cerebella of $p c d$ mice has shown that the vast majority of genes with altered transcriptional levels are related to functional categories such as cell death, developmental disorders, survival and glial responses [45,46].

\subsubsection{Degeneration of Purkinje Cells}

One of the phenotypic hallmarks of the pcd mutation in mice is early-onset cerebellar atrophy, which is mainly associated with drastic primary degeneration of PCs. Between two and four weeks of age, PCs rapidly degenerate, with only a few PCs remaining in lobule $X$ of the cerebellar vermis, which is preserved for a few additional weeks (Figure 4A,B) $[10,17,19,47]$. The degeneration of a massive number of PCs in pcd mice sequentially involves an initial "preneurodegenerative" stage, from postnatal day (P) 15 to P20, during which both cytoplasmic and nuclear alterations occur $[17,25,48,49]$, followed by a degenerative stage (P25-45), in which all cerebellar PCs degenerate (Figure 4C,D) [17,48], leading to an alteration in cerebellar-related motor performance. Interestingly, heterozygous pcd mice show a significant reduction in the number of PCs at P300, an observation that supports the idea that heterozygosity of the AGTPBP1 mutation may influence the ageing process, causing moderate PC degeneration [50]. 

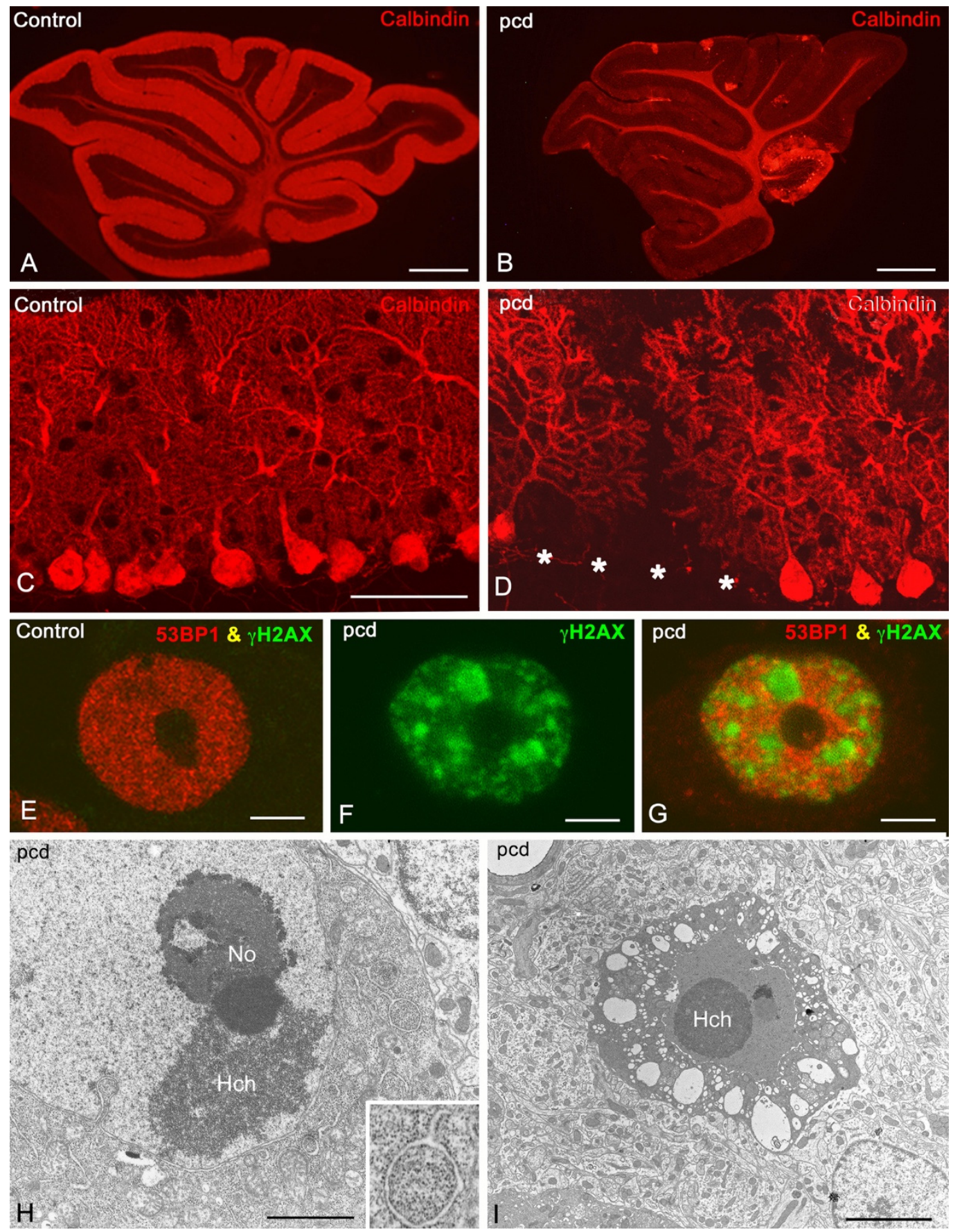

Figure 4. Degenerative features of the Purkinje cells in the $p c d$ mice. (A,B) Representative confocal microscopy images of sagittal sections of the vermis of P30 control (A) and P30 (B) pcd mutant mice immunolabelled for calbindin D-28k. Note that in the $p c d$ mouse there was a dramatic reduction in calbindin immunostaining in the molecular and PC layers resulting from the massive loss of PCs at P30 and that only PCs located in lobule X remained (arrow in B). Scale bars: 1 mm. (C,D) High magnification of calbindin D-28K immunolabelling of PC perikarya and their dendritic trees in control (C) and $p c d$ mice (D) at P20. Note the loss of PCs (white asterisks) in the $p c d$ mouse. Scale bar: $100 \mu \mathrm{m}$. (E-G) Confocal microscopy images of PC nuclei from control (E) and $p c d$ mice $(\mathbf{F}, \mathbf{G})$ at P20 double immunolabelled for the modified histone $\gamma \mathrm{H} 2 \mathrm{AX}$ (green), a marker of DNA double-strand breaks at sites of DNA damage, and p53-binding protein 1 (P53BP1, red), a key DNA repair factor. (E) Note the absence of $\gamma \mathrm{H} 2 \mathrm{AX}$ labelling and the typical diffuse nucleoplasmic distribution of 53BP1, in the control PC nucleus, excluding the nucleolus. $(\mathbf{F}, \mathbf{G})$ In contrast, the nucleus of the $p c d$ mouse shows prominent nuclear foci of DNA damage immunostained for $\gamma \mathrm{H} 2 \mathrm{AX}(\mathbf{F})$. Although the DNA repair factor 53BP1 was expressed in the nucleoplasm, it was not concentrated in $\gamma \mathrm{H} 2 \mathrm{AX}$-positive nuclear foci of DNA lesions $(\mathbf{G})$, indicating defective DNA repair. Scale bars: $5 \mu \mathrm{m}$. $(\mathbf{H})$ Electron 
microscopy image of PCs from $p c d$ mice at P20. Free polyribosomes were replaced by densely packed monoribosomes. Cytoplasmic portions containing monoribosomes appear sequestered in autophagic vacuoles bound by isolated RE cisternae (insert). Scale bar: $1 \mu \mathrm{m}$. (I) Electron microscopy image of mutant apoptotic PC Scale bars: $5 \mu \mathrm{m}$. (A,B) Adapted with permission from [17]. Copyright 2011 The Journal of Biological Chemistry. (C,D,H) Adapted with permission from [48]. Copyright 2011 Brain Pathology. (E-G) Adapted with permission from [49]. Copyright 2019 Neurobiology of Disease.

At the early stages of PC degeneration, alterations in the cytoarchitecture of the PCs, including disrupted dendrites, soma and axons, are already noticeable $[40,46]$. Ultrastructural analysis of axonal torpedoes has revealed organelle accumulation and cytoplasmic densification but the preservation of the myelin sheath [46]. This finding suggests that degeneration of axons is the primary defect and rules out the possibility that PCs degenerate following demyelination, as observed in the cerebral cortex in AGTPBP1-deficient mice [22]. AGTPBP1 loss of function affects dendritic tree development and architecture; however, these alterations do not seem to be directly involved in PC death $[19,25,40]$.

Another pre-degenerative characteristic of PCs is a reduction in perikaryal size [25]. Intriguingly, one of the earliest cytoplasmic morphological features of pre-degenerative PCs is the accumulation of free polyribosomes [19,47,51]. Polyribosome accumulation correlates with endoplasmic reticulum (ER) stress in the PCs of $p c d$ mice. In the initial stages of PC degeneration, the stacks of ER cisterns tend to disappear, and PCs show a prominent mass of densely packed free polyribosomes at the basal pole of PC somas. As degeneration proceeds, polyribosomes are disassembled into free monoribosomes [48]. A fraction of these free monoribosomes is sequestered in autophagic vacuoles for lysosomal degradation through a process termed ribophagy (Figure 4H) [48].

At the molecular level, upregulation of the expression of ER stress-related substrates and the unfolded protein response accompanied by downregulation of the expression of initiation factors for translation were detected in the mutant PCs [40,51,52]. Accumulation of hyperglutamylated tubulin in AGTPBP1-deficient PCs directly correlates with ER stress [51]. Other cytoplasmic alterations, such as the presence of abnormal mitochondria and reduced mitochondrial complex 1 activity, were also observed in mutant PCs [18,53].

The AGTPBP1 gene contains an NLS (Figure 1B) and encodes nuclear and cytoplasmic proteins [7]. However, little is known about its potential role in the neuronal nucleus. We performed an extensive analysis of the effects of AGTPBP1-deficiency in the PC's nuclear compartments involved in RNA transcription and processing and DNA damage repair, evaluating the impact of their dysfunction on neuronal homeostasis and survival $[17,48,49]$. During the pre-degenerative stage, in PCs, there is a progressive large-scale reorganisation of chromatin into large, transcriptionally silent, heterochromatin domains associated with the accumulation of DNA damage, which is one of the first signs of the PC preneurodegenerative stage of in $p c d$ mice [17].

To avoid the detrimental effects of DSBs, neurons exhibit a strong DNA repair response. However, growing evidence has indicated that defective DNA repair is the basis for brain ageing and several degenerative disorders [54]. In this context, a progressive accumulation of unrepaired DNA damage was detected in the PCs of $p c d$ mice (Figure 4E-G) [17,48]. Accordingly, defective DNA repair was implicated in the pathogenesis of several ataxias with a PC degeneration phenotype [55-60].

In addition to DNA damage and epigenetic changes in chromatin conformation, other nuclear compartments are affected in the mutant PCs. In particular, the disassembly of the Cajal bodies [61] and nucleolar disruption are directly correlated with the activation of nucleolar stress and defective ribosome biogenesis $[48,49]$. Nucleolar stress has been associated with several neurodegenerative human disorders, including Alzheimer's and Parkinson's diseases, ALS and spinal muscular atrophy, among others [62-68]. Moreover, a reduction in both nucleolar size and ribosome biogenesis occurs during ageing and is a key risk factor related to the onset of neurodegenerative disorders [54,69].

Consistent with all defined cytoplasmic and nuclear alterations, dysfunctional PCs in pcd mice ultimately activate the caspase-mediated apoptotic pathway (Figure 4I), in- 
cluding by upregulating the expression of neuronal apoptosis facilitators such as Bim3 and Bcl2111 [9,17-19,48,51,52,70]. In summary, some types of nuclear rearrangement and pathological alterations observed in PCs harbouring the pcd mutation resemble the cellular alterations described in certain human neurodegenerative diseases [66,71,72].

\subsubsection{Alterations in Other Neuronal Types in the Cerebella of $p c d$ Mice}

In the cerebella of $p c d$ mice, late secondary death of granule cells and neurons in the DCN and the inferior olivary complex, which is likely due to PC degeneration, occurs $[9,43,73]$. Remarkably, granule cells express the AGTPBP1 gene $[7,10]$. However, a significant reduction in granule cell number is only detected at 6 months of age, which progresses throughout the lifespan of the animal [9].

The loss of presynaptic afferents from PCs to the DCN results in decreased neuron survival $(\sim 30 \%)$ at advanced stages of neurodegeneration $[44,74]$. As a consequence of the abrogation of its major cortical target, the inferior olivary complex becomes atrophied subsequent to partial denervation in $p c d$ mice $[40,43,75]$. In particular, the number of neurons in the inferior olivary complex is reduced by half at 10 months of age, which then causes a reduction in the number of climbing fibres that reach the cerebellar cortex [75].

Finally, the disappearance of PCs in pcd mice stimulates severe gliosis $[40,46]$ and strikingly, oligodendrocytes and their precursors are markedly affected in the cerebellar cortex in $p c d$ mice [46].

\subsubsection{Reorganisation of Cerebellar Circuitry in pcd Mice after Purkinje Cell Loss}

The compensatory mechanisms in the cerebellar circuitry following PC loss in $p c d$ mice were examined [76]. Electrophysiological studies have revealed that despite the absence of PC-mediated tonic inhibition in the vestibular nucleus (VN) in $p c d$ mice, spontaneous activity is not greater in AGTPBP1-deficient neurons [76]. In addition, abrogation of $\mathrm{PC}$ input did not underlie disinhibition in neurons from the $\mathrm{VN}$ in $p c d$ mice [76]. The influence of PC input loss in VN neurons in regulating muscle contraction through the vestibulospinal pathway was also assessed. The response phase is slightly modified in the $p c d$ mice in comparison with control littermates. This effect may be partially involved in motor impairment [76].

The impact of AGTPBP1 deficiency on cerebellar neurotransmission was also evaluated. Abrogation of inputs originating from PCs reduces GABAergic inhibitory innervation and decreases the density of GABAA receptors in the DCN and VN [74,76]. In contrast, the glycinergic system was promoted in the DCN in $p c d$ mutant mice [74]. On the other hand, an increase in the number of glutamatergic synapses in both the DCN and the VN was detected, most likely due to enhanced mossy fibre innervation of the DCN and a secondary effect of reduced GABAergic-mediated inhibition in DCN neurons [74].

PCs and granule cells are specific targets for serotonergic neurons projecting from raphe nuclei and other brain areas. The serotonergic centrifugal system in the cerebella of $p c d$ mice becomes dysfunctional once PCs are completely depleted [77]. In particular, pcd mice showed a higher 5-HT-IR fibre density [78] and a reduction in the 5-HIAA/5-HT ratio [77]. Enhanced synthesis of 5-HT transporters and receptors was also detected in both the cerebellar cortex and DCN $[77,79]$. Together, these data point to a reduction in serotonergic modulation, indicating a decrease in serotonergic turnover in the $p c d$ cerebella [77].

Noradrenergic axon terminals from the locus coeruleus that reach the cerebellar cortex are preserved in $p c d$ mice despite the absence of $\mathrm{PCs}$, the targets of noradrenergic projections [80,81]. In addition, an increase in the density of norepinephrine fibres, most likely due to a reduction in cerebellar mass in $p c d$ mice, was also detected [81]. Likewise, a moderate increase in the levels of noradrenergic transporters and adrenergic receptors upon PC loss was observed [82]. Regarding the dopaminergic system, PC loss induces an increase in the levels of dopamine transporters in the DCN but a significant reduction in these levels in the molecular layer of the cerebellar cortex [83]. 


\subsubsection{Alterations in Cerebellar-Dependent Tasks}

A large battery of motor tests were used to evaluate the degree of cerebellar atrophy and the consequent impairment of locomotor coordination, as well as progressive weakness of musculature and cognitive decline in AGTPBP1-depleted mice.

Analysis of ataxic gait has revealed irregularly spaced and shorter steps in 4-week-old mutants, with this deficit becoming worse as cerebellar degeneration proceeds [14,40]. Severe early impairments in motor performance, in the rotarod test, which progressively deteriorates in parallel with PC death, were observed in $p c d$ mice $[14,17,19,25,40,84,85]$. It was demonstrated that in the treadmill motor assessment, $p c d$ mice have decreased body movement coordination [84]. Similarly, front-hind interlimb and whole-body coordination deficits were characterised using LocoMouse [86].

The grip strength and wire hang tests have revealed that $p c d$ mice experience muscle weakness [35,40]. In addition, the balance beam test has revealed that 4-week-old AGTPBP1 KO mice fall significantly more frequently than their wild-type counterparts [40].

Delayed eye-blinking conditioning appears to be severely affected and altered cerebellum-dependent learning is altered in adult $p c d$ mice [87], whereas trace eyeblink conditioning is unimpaired, suggesting that the cerebellum plays an indispensable role in the neuronal circuitry regulating this response [88]. The effects of cerebellar dysfunction on spatial learning in adult $p c d$ mice were determined using the Morris water maze test [89-91]. The novel object recognition test has revealed that long-term memory in $p c d$ mice is affected in the late stages of PC degeneration, and the results of the social preference test have suggested that PC loss in pcd mice affects social interaction [25]. Likewise, the results of the forced swimming test have suggested that $p c d$ mice exhibit depressive-like behaviour [91].

\subsection{Degeneration in the Olfactory Bulb}

\subsubsection{Degeneration of Mitral Cells}

The $\mathrm{OB}$ is considerably smaller in $p c d$ mice than in control animals, mainly due to the loss of MCs, the principal relay neurons in the olfactory pathway [5]. The loss of MCs is accompanied by reductions in the size of glomeruli and the thickness of the external plexiform layer. Other bulbar layers or neural elements are apparently unaffected by the loss of AGTPBP1 [8].

Degeneration of MCs occurs later and more slowly than that of PCs, taking place from P60 to P90 days $[8,20]$. While there is an extensive amount of data on the mechanisms underlying PC death, there is limited information regarding the mechanisms involved in MC degeneration. Similar to that of mutant PCs, degeneration of MCs is associated with ER stress, transcriptional repression, DNA damage and disruption of nucleoli and Cajal bodies, which ultimately cause apoptosis [20]. As in the cerebellum, tubulin hyperglutamylation in the $\mathrm{OB}$ was suggested to be a determinant of MC death in $p c d$ mice $[15,16]$.

$\mathrm{MC}$ degeneration induces reactive glial activation of astrocytes and microglia in the $\mathrm{OB}$. However, this response is milder than that detected in the cerebellum [46]. Curiously, bulbar oligodendrocytes are not affected in $p c d$ mice [46]. Differential glial responses observed in the cerebellum and the $\mathrm{OB}$ seem to correlate with the degree of neurodegeneration in each brain region and physiological AGTPBP1 expression levels [46].

\subsubsection{Reorganisation of Synaptic Circuitry after Mitral Cell Loss}

MCs establish reciprocal dendrodendritic synapses with bulbar granule cells. Although the pcd mutation does not compromise the viability of granule cells, MC degeneration prevents afferent inputs from contacting granule cells. Some granule cells establish new reciprocal dendrodendritic synapses with unaffected tufted cells [92]. However, it should be noted that mutant granule cells have an effect on the dendritic tree, including shortening dendrites and reducing the number of spines [93]. In contrast, afferent inputs reaching the OB from olfactory receptor cells are slightly affected by the loss of MCs [8].

MCs send axonal efferent inputs to the lateral olfactory tract. A general decrease in the thickness of the olfactory tract was found in $p c d$ mice [92], supporting the notion 
that the number of synapses declines upon MC degeneration. In addition, the diameter of terminal boutons increases, as does the number of multiple synaptic contacts, in $p c d$ mutants, suggesting further compensatory mechanisms for the loss of MC presynaptic terminals [92].

Centrifugal afferences from secondary olfactory structures to the OB upon MC loss were also examined. Strengthening of the centrifugal input to the OB from the anterior olfactory nucleus after MC loss was detected in pcd mice and is accompanied by complete loss of bilaterality in olfactory connections due to degeneration of the anterior commissure [94]. These results point to a dramatic reorganisation of this essential olfactory circuit between the anterior olfactory nucleus and the OB upon MC degeneration.

Regarding the dopaminergic system in the $\mathrm{OB}$, autoradiography studies have shown that dopamine receptor and transporter levels are not affected by AGTPBP1 loss of function [83]. Accordingly, tyrosine hydroxylase activity and immunoreactivity in OB juxtaglomerular neurons are more preserved in pcd mutants after MC degeneration than in heterozygous littermates [95].

The serotonergic system undergoes adaptive changes after, but not before, MC loss [96]. Degeneration of MCs causes a decrease in serotonergic input received by the OB, whereas the number of serotonergic cells in the raphe nuclei remains constant. In this regard, the neurotrophin BDNF and its main receptor TrkB exhibit altered expression in the OBs of $p c d$ animals even before the loss of MCs [96].

Although the expression of noradrenaline transporters is not affected by MC degeneration, variations in adrenergic receptors in some olfactory regions were defined, suggesting a local regulation of the NA system in regions influenced by MC loss [82]. The pcd mice also show reorganisation of zincergic centrifugal projections from the anterior olfactory nucleus to the $\mathrm{OB}$, indicating that plasticity occurs in response to MC loss [97].

\subsubsection{Neural Plasticity in the Olfactory Bulb after Mitral Cell Loss}

Neural progenitor cells from the rostral migratory stream differentiate into bulbar interneurons that modulate MC activity. Interestingly, changes in the proliferation rate, tangential and radial migration patterns and survival of newly generated neurons in $p c d$ mice were reported. Consequently, the absence of MCs in these mutants elicits differences in the final destination of the newly generated interneurons. Moreover, the depletion of MCs also alters the survival of the newly generated interneurons, in accordance with the decrease in the number of synaptic targets available [98].

\subsubsection{Alterations in Olfactory Task Performance after Mitral Cell Loss}

Despite the importance of the olfactory system in learning and affective behaviour in mice [99], little information about the potentially deleterious consequences of MC degeneration on olfactory-related task performance in $p c d$ mice is available. Using precision olfactometry, Diaz and colleagues showed that after MC death, pcd mutants exhibit poor odourant detection ability and limited odour discrimination ability [100]. In particular, $p c d$ mice are able to detect elevated, but not low, concentrations of odourants and discriminate them in a crude manner, suggesting the involvement of MCs in fine odour transmission and processing $[100,101]$.

\subsection{Degeneration in the Thalamus}

Discrete populations of thalamic neurons degenerate in $p c d$ mice between P50 and P60 and are nearly absent at P90 [21,102]. Thus, massive neuronal degeneration is observed in the central division of the mediodorsal nucleus, the ventral medial geniculate, posterior ventromedial and submedial nuclei, as well as portions of the ventrolateral and posteromedial nuclei that immediately surround the medial division of the ventrobasal complex. Degenerating thalamic neurons in the ventral medial geniculate nucleus, the main auditory thalamic area, show degenerative cellular hallmarks that resemble those reported for mutant PCs and MCs [102,103]. 
The electrophysiological and molecular changes in the ventral medial geniculate nucleus in $p c d$ mice were also examined [103]. Likewise, a progressive decrease in auditory evoked potentials and NMDA receptor-dependent fast oscillations in the auditory cortex were detected in $p c d$ mice [103].

Changes in the regional thalamic distribution of noradrenaline uptake sites, as well as in the expression of adrenergic receptors, were described following thalamic neuron loss in $p c d$ mice [82]. In addition, increased levels of dopamine receptors were found in the centromedian thalamic nucleus in $p c d$ mice [83].

\subsection{Degeneration in the Retina}

The onset of retinal degeneration of photoreceptors in $p c d$ mice occurs between 3 and 5 weeks of age, when approximately $50 \%$ of receptors are quickly lost [104,105]. Afterward, degeneration progresses quite slowly, with approximately $10 \%$ of the photoreceptors remaining by one year of age [104,105], and rods degenerating faster than cones [105]. The main photoreceptor alterations include abnormal accumulation of "bead-like" vesicles and ribosomes, disruption of the Golgi apparatus, and a significant reduction in the number of connecting cilia [106], which ultimately lead to the death of photoreceptors by apoptosis $[6,40,107]$. In addition, the pcd mutation in photoreceptors increases their vulnerability to the cellular stress produced by constant light exposure [108]. Progressive accumulation of polyglutamylated tubulin was detected in parallel with the degeneration of $p c d$ mutant photoreceptors [106]. Progressive loss of dendrites and disorganisation of axon terminals in retinal bipolar cells were also reported in parallel with degeneration of photoreceptors [41].

Consistent with cellular alterations, electroretinography of the $p c d$ mutant retina has revealed a progressive reduction in the amplitude of electrical signals in both rods and cones at advanced stages of degeneration in comparison with that in the control retina [41].

\subsection{Degeneration of Other Neuronal Types}

Quantitative estimation of the number of $\alpha$-motor neurons in the ventral horn of the lumbar spinal cord has revealed an approximately $50 \%$ reduction in the number of these cells in $p c d$ mice compared with control mice, which is accompanied by dysregulation of tubulin polyglutamylation [1]. Moreover, peripheral nerve degeneration with reduced motor nerve caliber, significant loss of myelinated axons and altered axon morphology were reported in $p c d$ mice [1].

As mentioned, one of the main pathological hallmarks in CONDCA patients is muscle weakness. Additionally, AGTPBP1 mRNA was found to be expressed in mouse skeletal muscle [12]. Muscle tissue organisation in $p c d$ mice was found to be hardly affected, with no obvious accumulation of collagen or fibrosis. However, the diameter of skeletal myofibres is reduced compared with that of control myofibres, most likely due to ataxia-derived atrophy (Figure 3E,F) [37] resulting from the decrease in the number of $\alpha$-motor neuron axons innervating the skeletal muscle [1]. As in other tissues affected by AGTPBP1 loss of function, whole-protein extracts from $p c d$ skeletal muscle exhibit higher levels of tubulin polyglutamylation than those from control skeletal muscle [15].

\subsection{Therapeutic Strategies}

Due to AGTPBP1 mutation-mediated primary neuronal death and the occurrence of secondary neurodegenerative processes in the $p c d$ mouse brain, this mouse model may serve as an attractive model for investigating new neuroprotective strategies to prevent, or at least attenuate, neurodegeneration. Most of the experimental therapies assessed in the $p c d$ mice presented here aimed to reverse cerebellar degeneration in $p c d$ mutants. Stem cell-based neuroregeneration or the use of molecules with neuroprotective potential are the main experimental approaches that were assessed in $p c d$ mice. 


\subsubsection{Stem Cell-Based Transplantation}

Under neurodegenerative conditions, grafted cells from healthy donors may provide neurotransmitters with neuroprotective potential, replace degenerated neurons and provide trophic support to surviving neurons. Based on this notion, embryonic cerebellar grafts appear to be a potential therapeutic strategy not only to replace PCs but also to prevent secondary neuronal death. Cells from solid embryonic cerebellar grafts from healthy donors implanted into 3-month-old $p c d$ mutants were able to migrate, settle and establish functional synapses in the host cerebellar cortex [109-113]. Similarly, suspended normal embryonic cerebellar cells transplanted into the $p c d$ mouse cerebellum were shown to survive and integrate with the degenerative harmful host environment, develop the characteristic PC cytoarchitecture and re-establish host-to-graft afferent innervation, while also ameliorating motor deficits [114-119].

Bone marrow-derived stem cell (BMDSC) transplantation also appears to be a therapeutic option for ameliorating neurodegeneration in $p c d$ mice. Initial studies have indicated that grafted BMDSCs in $p c d$ mice are able to migrate and reach the degenerating cerebellum and OB, although most of them differentiate into glial cells [120]. Posterior bone marrow transplantation notably improves skeletal muscle tissue organisation rather than attenuating neurodegeneration, which correlates with a partial but significant restoration of locomotor performance [37]. Thus, recovery of muscular dysfunction appears to be the basis of this locomotor improvement. BMDSC transplantation in $p c d$ mice also results in the attenuation of MC degeneration and an associated improvement in odour detection [100]. Limitations of this approach include that the delivery of healthy BMDSCs to the damaged site is not fast enough to stop neuronal loss over time. Thus, optimisation of this technique by ensuring a regular supply of healthy stem cells through continuous, daily transplants would increase the population of pluripotent cells that reach the target tissue and potentially fuse with unaffected mutant PCs, increasing their survival [121].

An additional limitation is the physical barrier of the granule cell layer, which impedes healthy grafted cells from reaching the PC layer. In addition, the complexity of cerebellar circuitry is too great for it to be finely reconstructed. Moreover, the purposed fate of grafted cells is strictly regulated by a large variety of factors that may vary according to each degenerative environment. Therefore, neurotransplantation and stem cell-based therapy in patients with cerebellar degeneration are still far from being practical [122].

\subsubsection{Preservation of Degenerating Neurons in $p c d$ Mice}

Other experimental approaches have aimed to protect and preserve mutant PCs through the administration of neuroprotective molecules, the exogenous administration of functional AGTPBP1 and the directed modulation of specific signalling pathways involved in the degeneration of PCs in $p c d$ mice.

The neuroprotective role of insulin-like growth factor (IGF-I) was shown, and IGFI has been extensively used to treat several neurodegenerative disorders. Interestingly, reduced levels of IGF-I were found in patients with cerebellar dysfunction and ataxia [123]. Consistently, IGF-1 administration in $p c d$ mice was shown to significantly increase body weight and survival and improve motor performance [124]. Interestingly, administration of IGF-1 in patients with autosomal dominant cerebellar ataxia delays the progression of the disease and appears to be a potentially promising therapeutic option for CONDCA patients [125]. In addition, oleoylethanolamide, an endocannabinoid compound, was proposed to prevent neuronal damage, delay PC death and ameliorate cognitive decline in pcd mice [126].

Affectation in the auditory cortex in $p c d$ mice following thalamic neuron degeneration is closely related to a marked upregulation of NMDA expression. Accordingly, the administration of an NMDA antagonist restores the electrophysiological response evoked in the auditory cortex in $p c d$ mice [103].

Another important target of neuroprotective agents is the modulation of the glial response. Accordingly, a harmful glial response in the cerebella of $p c d$ mice could be 
directly related to the rapid degeneration of PCs [46]. In this regard, attenuation of glial activation following minocycline administration delays the death of PCs in $p c d$ mice and mildly improves their locomotor performance [52]. Thus, administration of glial activation inhibitors or genetic modulation of the glial response may be considered potential therapeutic approaches to ameliorate neurodegenerative disorders [127].

\subsubsection{Genetically Mediated Therapeutic Approaches}

Genetically mediated restoration of functional AGTPBP1 expression in both the cerebellum and the retina is sufficient to rescue PC and photoreceptor degeneration in $p c d$ mice $[14,30]$. As mentioned above, AGTPBP1 loss of function leads to excessive tubulin polyglutamylation, which seems to be the main cause of neurodegeneration in $p c d$ mice. Based on this notion, the abnormal accumulation of polyglutamylation in the mutant cerebellum may be rescued by inactivation of the polyglutamylase tubulin-tyrosine ligase-like 1 (TTL1), resulting in almost complete preservation of PCs in the $p c d$ mouse cerebellum [22]. This raises the possibility that pharmacologically mediated regulation of enzymes counteracting AGTPBP1-mediated reactions, such as TTL1, could be considered a new therapeutic approach for the treatment of AGTPBP1-related diseases.

\section{Conclusions}

Here, we summarise the most recent experimental findings that support AGTPBP1 as the gene responsible for the development of CONDCA in humans. Additionally, the pathogenic events that occur in $p c d$ mice, which harbours loss-of-function mutations in the $A G T P B P 1$ gene, are described in-depth and summarised in the graphical abstract. The fact that the pathological characteristics of the pcd mutation share clear similarities with those of CONDCA patients indicates that AGTPBP1 function is essential to the development of neurological disorders not only in mice but also in humans. In this regard, it is evident that the $p c d$ mouse appears as a promising model for the development of new therapeutic strategies for clinical trials in humans. Polyglutamylation inhibition was recently described as a promising therapeutic option for CONDCA patients. This line of investigation together with others involving the use of $p c d$ mice and those included in this review may be considered in the future as therapeutic options for CONDCA treatment.

Author Contributions: F.C.B. wrote the review. M.T.B., E.S. and M.L. participated in revising and editing the final version of the manuscript and the figures. All authors have read and agreed to the published version of the manuscript.

Funding: This work was supported by funding received by the Institute of Health Carlos III (CIBERONC, CB16/12/00352 and CIBERNED, CB/05/0037), the Valdecilla Research Institute (IDIVAL, Santander Spain), the Regional Government of Castile and Leon, funds received by the European Regional Development Fund (SA264P18-UIC076; University of Salamanca, Spain) and the Samuel-Solórzano Barruso Foundation (FS/32-2020, University of Salamanca, Spain).

Institutional Review Board Statement: Not applicable.

Informed Consent Statement: Not applicable.

Acknowledgments: We thank Ana Canga from the "Hospital Universitario Marqués de Valdecilla", Santander (Spain) for gently provide MRI images from a control individual.

Conflicts of Interest: The authors declare no conflict of interest.

\section{References}

1. Shashi, V.; Magiera, M.M.; Klein, D.; Zaki, M.; Schoch, K.; Rudnik-Schöneborn, S.; Norman, A.; Lopes Abath Neto, O.; Dusl, M.; Yuan, X.; et al. Loss of tubulin deglutamylase CCP1 causes infantile-onset neurodegeneration. EMBO J. 2018, 37 , e100540. [CrossRef] [PubMed]

2. Sheffer, R.; Gur, M.; Brooks, R.; Salah, S.; Daana, M.; Fraenkel, N.; Eisenstein, E.; Rabie, M.; Nevo, Y.; Jalas, C.; et al. Biallelic variants in AGTPBP1, involved in tubulin deglutamylation, are associated with cerebellar degeneration and motor neuropathy. Eur. J. Hum. Genet. 2019, 27, 1419-1426. [CrossRef] [PubMed] 
3. Karakaya, M.; Paketci, C.; Altmueller, J.; Thiele, H.; Hoelker, I.; Yis, U.; Wirth, B. Biallelic variant in AGTPBP1 causes infantile lower motor neuron degeneration and cerebellar atrophy. Am. J. Med. Genet. A 2019, 179, 1580-1584. [CrossRef] [PubMed]

4. Maddirevula, S.; Alzahrani, F.; Al-Owain, M.; Al Muhaizea, M.A.; Kayyali, H.R.; AlHashem, A.; Rahbeeni, Z.; Al-Otaibi, M.; Alzaidan, H.I.; Balobaid, A.; et al. Autozygome and high throughput confirmation of disease genes candidacy. Genet. Med. 2019, 21, 736-742. [CrossRef]

5. Mullen, R.J.; Eicher, E.M.; Sidman, R.L. Purkinje cell degeneration, a new neurological mutation in the mouse. Proc. Natl. Acad. Sci. USA 1976, 73, 208-212. [CrossRef]

6. Blanks, J.C.; Mullen, R.J.; Lavail, M.M. Retinal degeneration in thepcd cerebellar mutant mouse. II. Electron microscopic analysis. J. Comp. Neurol. 1982, 212, 231-246. [CrossRef]

7. Harris, A.; Morgan, J.I.; Pecot, M.; Soumare, A.; Osborne, A.; Soares, H.D. Regenerating motor neurons express Nna1, a novel ATP/GTP-binding protein related to zinc carboxypeptidases. Mol. Cell. Neurosci. 2000, 16, 578-596. [CrossRef]

8. Greer, C.A.; Shepherd, G.M. Mitral cell degeneration and sensory function in the neurological mutant mouse Purkinje cell degeneration (PCD). Brain Res. 1982, 235, 156-161. [CrossRef]

9. Wang, T.; Morgan, J.I. The Purkinje cell degeneration (pcd) mouse: An unexpected molecular link between neuronal degeneration and regeneration. Brain Res. 2007, 1140, 26-40. [CrossRef]

10. Fernandez-Gonzalez, A.; La Spada, A.R.; Treadaway, J.; Higdon, J.C.; Harris, B.S.; Sidman, R.L.; Morgan, J.I.; Zuo, J. Purkinje cell degeneration (pcd) phenotypes caused by mutations in the axotomy-induced gene, Nna1. Science 2002, 295, 1904-1906. [CrossRef]

11. Zhao, X.; Onteru, S.K.; Dittmer, K.E.; Parton, K.; Blair, H.T.; Rothschild, M.F.; Garrick, D.J. A missense mutation in AGTPBP1 was identified in sheep with a lower motor neuron disease. Heredity 2012, 109, 156-162. [CrossRef] [PubMed]

12. Kalinina, E.; Biswas, R.; Berezniuk, I.; Hermoso, A.; Aviles, F.X.; Fricker, L.D. A novel subfamily of mouse cytosolic carboxypeptidases. FASEB J. 2007, 21, 836-850. [CrossRef] [PubMed]

13. Vega, M.R.; Sevilla, R.G.; Hermoso, A.; Lorenzo, J.; Tanco, S.; Diez, A.; Fricker, L.D.; Bautista, J.M.; Aviles, F.X. Nnal-like proteins are active metallocarboxypeptidases of a new and diverse M14 subfamily. FASEB J. 2007, 21, 851-865. [CrossRef] [PubMed]

14. Wang, T.; Parris, J.; Li, L.; Morgan, J.I. The carboxypeptidase-like substrate-binding site in Nna1 is essential for the rescue of the Purkinje cell degeneration (pcd) phenotype. Mol. Cell. Neurosci. 2006, 33, 200-213. [CrossRef]

15. Rogowski, K.; van Dijk, J.; Magiera, M.M.; Bosc, C.; Deloulme, J.-C.; Bosson, A.; Peris, L.; Gold, N.D.; Lacroix, B.; Bosch Grau, M.; et al. A family of protein-deglutamylating enzymes associated with neurodegeneration. Cell 2010, 143, 564-578. [CrossRef]

16. Berezniuk, I.; Vu, H.T.; Lyons, P.J.; Sironi, J.J.; Xiao, H.; Burd, B.; Setou, M.; Angeletti, R.H.; Ikegami, K.; Fricker, L.D. Cytosolic carboxypeptidase 1 is involved in processing $\alpha$ - and $\beta$-tubulin. J. Biol. Chem. 2012, 287, 6503-6517. [CrossRef]

17. Baltanás, F.C.; Casafont, I.; Lafarga, V.; Weruaga, E.; Alonso, J.R.; Berciano, M.T.; Lafarga, M. Purkinje Cell Degeneration in pcd Mice Reveals Large Scale Chromatin Reorganization and Gene Silencing Linked to Defective DNA Repair. J. Biol. Chem. 2011, 286, 28287-28302. [CrossRef]

18. Chakrabarti, L.; Zahra, R.; Jackson, S.M.; Kazemi-Esfarjani, P.; Sopher, B.L.; Mason, A.G.; Toneff, T.; Ryu, S.; Shaffer, S.; Kansy, J.W.; et al. Mitochondrial Dysfunction in NnaD Mutant Flies and Purkinje Cell Degeneration Mice Reveals a Role for Nna Proteins in Neuronal Bioenergetics. Neuron 2010, 66, 835-847. [CrossRef]

19. Li, J.; Gu, X.; Ma, Y.; Calicchio, M.L.; Kong, D.; Teng, Y.D.; Yu, L.; Crain, A.M.; Vartanian, T.K.; Pasqualini, R.; et al. Nna1 mediates purkinje cell dendritic development via lysyl oxidase propeptide and NF-кB signaling. Neuron 2010, 68, 45-60. [CrossRef]

20. Valero, J.; Berciano, M.T.; Weruaga, E.; Lafarga, M.; Alonso, J.R. Pre-neurodegeneration of mitral cells in the pcd mutant mouse is associated with DNA damage, transcriptional repression, and reorganization of nuclear speckles and Cajal bodies. Mol. Cell. Neurosci. 2006, 33, 283-295. [CrossRef]

21. O'Gorman, S.; Sidman, R.L. Degeneration of thalamic neurons in? Purkinje cell degeneration? mutant mice. I. Distribution of neuron loss. J. Comp. Neurol. 1985, 234, 277-297. [CrossRef] [PubMed]

22. Magiera, M.M.; Bodakuntla, S.; Žiak, J.; Lacomme, S.; Marques Sousa, P.; Leboucher, S.; Hausrat, T.J.; Bosc, C.; Andrieux, A.; Kneussel, M.; et al. Excessive tubulin polyglutamylation causes neurodegeneration and perturbs neuronal transport. $E M B O J$. 2018, 37, e100440. [CrossRef]

23. Strzyz, P. Neurodegenerative polyglutamylation. Nat. Rev. Mol. Cell Biol. 2019, 20, 1. [CrossRef]

24. Bodakuntla, S.; Schnitzler, A.; Villablanca, C.; Gonzalez-Billault, C.; Bieche, I.; Janke, C.; Magiera, M.M. Tubulin polyglutamylation is a general traffic control mechanism in hippocampal neurons. J. Cell Sci. 2020, 133, jcs241802. [CrossRef] [PubMed]

25. Muñoz-Castañeda, R.; Díaz, D.; Peris, L.; Andrieux, A.; Bosc, C.; Muñoz-Castañeda, J.M.; Janke, C.; Alonso, J.R.; Moutin, M.-J.; Weruaga, E. Cytoskeleton stability is essential for the integrity of the cerebellum and its motor- and affective-related behaviors. Sci. Rep. 2018, 8, 3072. [CrossRef]

26. De La Vega Otazo, M.R.; Lorenzo, J.; Tort, O.; Avilés, F.X.; Bautista, J.M. Functional segregation and emerging role of cilia-related cytosolic carboxypeptidases (CCPs). FASEB J. 2013, 27, 424-431. [CrossRef]

27. Lyons, P.J.; Sapio, M.R.; Fricker, L.D. Zebrafish cytosolic carboxypeptidases 1 and 5 are essential for embryonic development. J. Biol. Chem. 2013, 288, 30454-30462. [CrossRef]

28. Kimura, Y.; Kurabe, N.; Ikegami, K.; Tsutsumi, K.; Konishi, Y.; Kaplan, O.I.; Kunitomo, H.; Iino, Y.; Blacque, O.E.; Setou, M. Identification of tubulin deglutamylase among Caenorhabditis elegans and mammalian cytosolic carboxypeptidases (CCPs). J. Biol. Chem. 2010, 285, 22936-22941. [CrossRef] [PubMed] 
29. Wu, H.Y.; Wang, T.; Li, L.; Correia, K.; Morgan, J.I. A structural and functional analysis of Nna1 in Purkinje cell degeneration (pcd) mice. FASEB J. 2012, 26, 4468-4480. [CrossRef]

30. Chakrabarti, L.; Eng, J.; Martinez, R.A.; Jackson, S.; Huang, J.; Possin, D.E.; Sopher, B.L.; La Spada, A.R. The zinc-binding domain of Nna1 is required to prevent retinal photoreceptor loss and cerebellar ataxia in Purkinje cell degeneration (pcd) mice. Vis. Res. 2008, 48, 1999-2005. [CrossRef]

31. Conde, C.; Cáceres, A. Microtubule assembly, organization and dynamics in axons and dendrites. Nat. Rev. Neurosci. 2009, 10, 319-332. [CrossRef]

32. Bulinski, J.C. Microtubules and Neurodegeneration: The Tubulin Code Sets the Rules of the Road. Curr. Biol. 2019, 29, R28-R30. [CrossRef] [PubMed]

33. Janke, C. The tubulin code: Molecular components, readout mechanisms, functions. J. Cell Biol. 2014, 206, 461-472. [CrossRef] [PubMed]

34. Tanco, S.; Tort, O.; Demol, H.; Aviles, F.X.; Gevaert, K.; Van Damme, P.; Lorenzo, J. C-terminomics Screen for Natural Substrates of Cytosolic Carboxypeptidase 1 Reveals Processing of Acidic Protein C termini. Mol. Cell. Proteom. 2015, 14, 177-190. [CrossRef] [PubMed]

35. Gilmore-Hall, S.; Kuo, J.; Ward, J.M.; Zahra, R.; Morrison, R.S.; Perkins, G.; La Spada, A.R. CCP1 promotes mitochondrial fusion and motility to prevent Purkinje cell neuron loss in pcd mice. J. Cell Biol. 2018, 218, 206-219. [CrossRef]

36. Türay, S.; Eröz, R.; Başak, A.N. A novel pathogenic variant in the $3^{\prime}$ end of the AGTPBP1 gene gives rise to neurodegeneration without cerebellar atrophy: An expansion of the disease phenotype? Neurogenetics 2021, 22, 127-132. [CrossRef] [PubMed]

37. Díaz, D.; Piquer-Gil, M.; Recio, J.S.; Martínez-Losa, M.M.; Alonso, J.R.; Weruaga, E.; Álvarez-Dolado, M. Bone marrow transplantation improves motor activity in a mouse model of ataxia. J. Tissue Eng. Regen. Med. 2018, 12, e1950-e1961. [CrossRef]

38. Akhmanova, A.; Hoogenraad, C.C. More is not always better: Hyperglutamylation leads to neurodegeneration. EMBO J. 2018, 37, e101023. [CrossRef]

39. Kitano, S.; Kino, Y.; Yamamoto, Y.; Takitani, M.; Miyoshi, J.; Ishida, T.; Saito, Y.; Arima, K.; Satoh, J.-I. Bioinformatics Data Mining Approach Suggests Coexpression of AGTPBP1 with an ALS-linked Gene C9orf72. J. Cent. Nerv. Syst. Dis. 2015, 7, 15-26. [CrossRef] [PubMed]

40. Zhou, L.; Hossain, M.I.; Yamazaki, M.; Abe, M.; Natsume, R.; Konno, K.; Kageyama, S.; Komatsu, M.; Watanabe, M.; Sakimura, K.; et al. Deletion of exons encoding carboxypeptidase domain of Nna1 results in Purkinje cell degeneration (pcd) phenotype. J. Neurochem. 2018, 147, 557-572. [CrossRef] [PubMed]

41. Marchena, M.; Lara, J.; Aijón, J.; Germain, F.; de la Villa, P.; Velasco, A. The retina of the PCD/PCD mouse as a model of photoreceptor degeneration. A structural and functional study. Exp. Eye Res. 2011, 93, 607-617. [CrossRef] [PubMed]

42. Zhang, W.; Ghetti, B.; Lee, W.H. Decreased IGF-I gene expression during the apoptosis of Purkinje cells in pcd mice. Dev. Brain Res. 1997, 98, 164-176. [CrossRef]

43. Ghetti, B.; Norton, J.; Triarhou, L.C. Nerve cell atrophy and loss in the inferior olivary complex of "Purkinje cell degeneration" mutant mice. J. Comp. Neurol. 1987, 260, 409-422. [CrossRef] [PubMed]

44. Triarhou, L.C.; Norton, J.; Ghetti, B. Anterograde transsynaptic degeneration in the deep cerebellar nuclei of Purkinje cell degeneration (pcd) mutant mice. Exp. Brain Res. 1987, 66, 577-588. [CrossRef] [PubMed]

45. Ford, G.D.; Ford, B.D.; Steele, E.C.; Gates, A.; Hood, D.; Matthews, M.A.B.; Mirza, S.; MacLeish, P.R. Analysis of transcriptional profiles and functional clustering of global cerebellar gene expression in PCD3J mice. Biochem. Biophys. Res. Commun. 2008, 377, 556-561. [CrossRef]

46. Baltanás, F.C.; Berciano, M.T.; Valero, J.; Gómez, C.; Díaz, D.; Alonso, J.R.; Lafarga, M.; Weruaga, E. Differential glial activation during the degeneration of Purkinje cells and mitral cells in the PCD mutant mice. Glia 2013, 61, 254-272. [CrossRef] [PubMed]

47. Landis, S.C.; Mullen, R.J. The development and degeneration of Purkinje cells in pcd mutant mice. J. Comp. Neurol. 1978, 177, 125-143. [CrossRef]

48. Baltanás, F.C.; Casafont, I.; Weruaga, E.; Alonso, J.R.; Berciano, M.T.; Lafarga, M. Nucleolar Disruption and Cajal Body Disassembly are Nuclear Hallmarks of DNA Damage-Induced Neurodegeneration in Purkinje Cells. Brain Pathol. 2011, 21, 374-388. [CrossRef]

49. Baltanás, F.C.; Berciano, M.T.; Tapia, O.; Narcis, J.O.; Lafarga, V.; Díaz, D.; Weruaga, E.; Santos, E.; Lafarga, M. Nucleolin reorganization and nucleolar stress in Purkinje cells of mutant PCD mice. Neurobiol. Dis. 2019, 127, 312-322. [CrossRef] [PubMed]

50. Díaz, D.; Recio, J.S.; Weruaga, E.; Alonso, J.R. Mild cerebellar neurodegeneration of aged heterozygous PCD mice increases cell fusion of Purkinje and bone marrow-derived cells. Cell Transplant. 2012, 21, 1595-1602. [CrossRef]

51. Li, J.; Snyder, E.Y.; Tang, F.H.F.; Pasqualini, R.; Arap, W.; Sidman, R.L. Nna1 gene deficiency triggers Purkinje neuron death by tubulin hyperglutamylation and ER dysfunction. JCI Insight 2020, 5, e136078. [CrossRef]

52. Kyuhou, S.I.; Kato, N.; Gemba, H. Emergence of endoplasmic reticulum stress and activated microglia in Purkinje cell degeneration mice. Neurosci. Lett. 2006, 396, 91-96. [CrossRef] [PubMed]

53. Pollard, A.K.; Craig, E.L.; Chakrabarti, L. Mitochondrial complex 1 activity measured by spectrophotometry is reduced across all brain regions in ageing and more specifically in neurodegeneration. PLoS ONE 2016, 11, e0157405. [CrossRef] [PubMed]

54. Chow, H.; Herrup, K. Genomic integrity and the ageing brain. Nat. Rev. Neurosci. 2015, 16, 672-684. [CrossRef]

55. Date, H.; Onodera, O.; Tanaka, H.; Iwabuchi, K.; Uekawa, K.; Igarashi, S.; Koike, R.; Hiroi, T.; Yuasa, T.; Awaya, Y.; et al. Early-onset ataxia with ocular motor apraxia and hypoalbuminemia is caused by mutations in a new HIT superfamily gene. Nat. Genet. 2001, 29, 184-188. [CrossRef] [PubMed] 
56. Enokido, Y.; Tamura, T.; Ito, H.; Arumughan, A.; Komuro, A.; Shiwaku, H.; Sone, M.; Foulle, R.; Sawada, H.; Ishiguro, H.; et al. Mutant huntingtin impairs Ku70-mediated DNA repair. J. Cell Biol. 2010, 189, 425-443. [CrossRef]

57. Suraweera, A.; Becherel, O.J.; Chen, P.; Rundle, N.; Woods, R.; Nakamura, J.; Gatei, M.; Criscuolo, C.; Filla, A.; Chessa, L.; et al. Senataxin, defective in ataxia oculomotor apraxia type 2, is involved in the defense against oxidative DNA damage. J. Cell Biol. 2007, 177, 969-979. [CrossRef] [PubMed]

58. Takashima, H.; Boerkoel, C.F.; John, J.; Saifi, G.M.; Salih, M.A.M.; Armstrong, D.; Mao, Y.; Quiocho, F.A.; Roa, B.B.; Nakagawa, M.; et al. Mutation of TDP1, encoding a topoisomerase I-dependent DNA damage repair enzyme, in spinocerebellar ataxia with axonal neuropathy. Nat. Genet. 2002, 32, 267-272. [CrossRef]

59. Rass, U.; Ahel, I.; West, S.C. Defective DNA Repair and Neurodegenerative Disease. Cell 2007, 130, 991-1004. [CrossRef]

60. Shackelford, D.A. DNA end joining activity is reduced in Alzheimer's disease. Neurobiol. Aging 2006, 27, 596-605. [CrossRef] [PubMed]

61. Lafarga, M.; Casafont, I.; Bengoechea, R.; Tapia, O.; Berciano, M.T. Cajal's contribution to the knowledge of the neuronal cell nucleus. Chromosoma 2009, 118, 437-443. [CrossRef] [PubMed]

62. Rieker, C.; Engblom, D.; Kreiner, G.; Domanskyi, A.; Schober, A.; Stotz, S.; Neumann, M.; Yuan, X.; Grummt, I.; Schütz, G.; et al. Nucleolar disruption in dopaminergic neurons leads to oxidative damage and parkinsonism through repression of mammalian target of rapamycin signaling. J. Neurosci. 2011, 31, 453-460. [CrossRef] [PubMed]

63. Hetman, M.; Pietrzak, M. Emerging roles of the neuronal nucleolus. Trends Neurosci. 2012, 35, 305-314. [CrossRef] [PubMed]

64. Parlato, R.; Kreiner, G. Nucleolar activity in neurodegenerative diseases: A missing piece of the puzzle? J. Mol. Med. 2013, 91, 541-547. [CrossRef]

65. Garcia-Esparcia, P.; Sideris-Lampretsas, G.; Hernandez-Ortega, K.; Grau-Rivera, O.; Sklaviadis, T.; Gelpi, E.; Ferrer, I. Altered mechanisms of protein synthesis in frontal cortex in Alzheimer disease and a mouse model. Am. J. Neurodegener. Dis. 2017, 6, $15-25$.

66. Hernández-Ortega, K.; Garcia-Esparcia, P.; Gil, L.; Lucas, J.J.; Ferrer, I. Altered Machinery of Protein Synthesis in Alzheimer's: From the Nucleolus to the Ribosome. Brain Pathol. 2016, 26, 593-605. [CrossRef] [PubMed]

67. Tapia, O.; Narcís, J.O.; Riancho, J.; Tarabal, O.; Piedrafita, L.; Calderó, J.; Berciano, M.T.; Lafarga, M. Cellular bases of the RNA metabolism dysfunction in motor neurons of a murine model of spinal muscular atrophy: Role of Cajal bodies and the nucleolus. Neurobiol. Dis. 2017, 108, 83-99. [CrossRef] [PubMed]

68. Haeusler, A.R.; Donnelly, C.J.; Periz, G.; Simko, E.A.J.; Shaw, P.G.; Kim, M.-S.; Maragakis, N.J.; Troncoso, J.C.; Pandey, A.; Sattler, R.; et al. C9orf72 nucleotide repeat structures initiate molecular cascades of disease. Nature 2014, 507, 195-200. [CrossRef]

69. Mattson, M.P.; Magnus, T. Ageing and neuronal vulnerability. Nat. Rev. Neurosci. 2006, 7, 278-294. [CrossRef]

70. Berezniuk, I.; Fricker, L.D. A defect in cytosolic carboxypeptidase 1 (Nna1) causes autophagy in Purkinje cell degeneration mouse brain. Autophagy 2010, 6, 558-559. [CrossRef]

71. El-Bazzal, L.; Rihan, K.; Bernard-Marissal, N.; Castro, C.; Chouery-Khoury, E.; Desvignes, J.P.; Atkinson, A.; Bertaux, K.; Koussa S.; Lévy, N.; et al. Loss of Cajal bodies in motor neurons from patients with novel mutations in VRK1. Hum. Mol. Genet. 2019, 28, 2378-2394. [CrossRef]

72. Pessina, F.; Gioia, U.; Brandi, O.; Farina, S.; Ceccon, M.; Francia, S.; d'Adda di Fagagna, F. DNA Damage Triggers a New Phase in Neurodegeneration. Trends Genet. 2020, 337-354.

73. Zhou, L.; Araki, A.; Nakano, A.; Sezer, C.; Harada, T. Different types of neural cell death in the cerebellum of the ataxia and male sterility (AMS) mutant mouse. Pathol. Int. 2006, 56, 173-180. [CrossRef] [PubMed]

74. Blosa, M.; Bursch, C.; Weigel, S.; Holzer, M.; Jäger, C.; Janke, C.; Matthews, R.T.; Arendt, T.; Morawski, M. Reorganization of synaptic connections and perineuronal nets in the deep cerebellar nuclei of purkinje cell degeneration mutant mice. Neural Plast. 2016, 2016, 2828536. [CrossRef] [PubMed]

75. Triarhou, L.C.; Ghetti, B. Stabilisation of neurone number in the inferior olivary complex of aged "Purkinje cell degeneration" mutant mice. Acta Neuropathol. 1991, 81, 597-602. [CrossRef]

76. Grüsser-Cornehls, U.; Bäurle, J. Mutant mice as a model for cerebellar ataxia. Prog. Neurobiol. 2001, 63, 489-540. [CrossRef]

77. Ghetti, B.; Perry, K.W.; Fuller, R.W. Serotonin concentration and turnover in cerebelum and other brain regions of pcd mutant mice. Brain Res. 1988, 458, 367-371. [CrossRef]

78. Triarhou, L.C.; Ghetti, B. Serotonin-immunoreactivity in the cerebellum of two neurological mutant mice and the corresponding wild-type genetic stocks. J. Chem. Neuroanat. 1991, 4, 421-428. [CrossRef]

79. Le Marec, N.; Hébert, C.; Amdiss, F.; Botez, M.I.; Reader, T.A. Regional distribution of 5-HT transporters in the brain of wild type and "Purkinje cell degeneration" mutant mice: A quantitative autoradiographic study with [3H]citalopram. J. Chem. Neuroanat. 1998, 15, 155-171. [CrossRef]

80. Felten, D.L.; Felten, S.Y.; Perry, K.W.; Fuller, R.W.; Nurnberger, J.I.; Ghetti, B. Noradrenergic innervation of the cerebellar cortex in normal and in Purkinje cell degeneration mutant mice: Evidence for long term survival following loss of the two major cerebellar cortical neuronal populations. Neuroscience 1986, 18, 783-793. [CrossRef]

81. Roffler-Tarlov, S.; Landis, S.C.; Zigmond, M.J. Effects of Purkinje cell degeneration on the noradrenergic projection to mouse cerebellar cortex. Brain Res. 1984, 298, 303-311. [CrossRef]

82. Strazielle, C.; Lalonde, R.; Hébert, C.; Reader, T.A. Regional brain distribution of noradrenaline uptake sites, and of $\alpha 1-, \alpha 2-$ and $\beta$-adrenergic receptors in PCD mutant mice: A quantitative autoradiographic study. Neuroscience 1999, 94, 287-304. [CrossRef] 
83. Delis, F.; Mitsacos, A.; Giompres, P. Dopamine receptor and transporter levels are altered in the brain of Purkinje Cell Degeneration mutant mice. Neuroscience 2004, 125, 255-268. [CrossRef]

84. Le Marec, N.; Lalonde, R. Sensorimotor learning and retention during equilibrium tests in Purkinje cell degeneration mutant mice. Brain Res. 1997, 768, 310-316. [CrossRef]

85. Wu, H.Y.; Rong, Y.; Correia, K.; Min, J.; Morgan, J.I. Comparison of the Enzymatic and Functional Properties of Three Cytosolic Carboxypeptidase Family Members. J. Biol. Chem. 2015, 290, 1222-1232. [CrossRef] [PubMed]

86. Machado, A.S.; Darmohray, D.M.; Fayad, J.; Marques, H.G.; Carey, M.R. A quantitative framework for whole-body coordination reveals specific deficits in freely walking ataxic mice. Elife 2015, 4, e07892. [CrossRef]

87. Chen, L.; Bao, S.; Lockard, J.M.; Kim, J.J.; Thompson, R.F. Impaired classical eyeblink conditioning in cerebellar-lesioned and Purkinje cell degeneration (pcd) mutant mice. J. Neurosci. 1996, 16, 2829-2838. [CrossRef]

88. Brown, K.L.; Agelan, A.; Woodruff-Pak, D.S. Unimpaired trace classical eyeblink conditioning in Purkinje cell degeneration (pcd) mutant mice. Neurobiol. Learn. Mem. 2010, 93, 303-311. [CrossRef]

89. Goodlett, C.R.; Hamre, K.M.; West, J.R. Dissociation of spatial navigation and visual guidance performance in Purkinje cell degeneration (pcd) mutant mice. Behav. Brain Res. 1992, 47, 129-141. [CrossRef]

90. Lalonde, R.; Strazielle, C. The effects of cerebellar damage on maze learning in animals. Cerebellum 2003, 2, 300-309.

91. Tuma, J.; Kolinko, Y.; Vozeh, F.; Oendelint, J. Mutation-related differences in exploratory, spatial, and depressive-like behavior in pcd and Lurcher cerebellar mutant mice. Front. Behav. Neurosci. 2015, 9, 116. [CrossRef]

92. Bartolomei, J.C.; Greer, C.A. The organization of piriform cortex and the lateral olfactory tract following the loss of mitral cells in PCD mice. Exp. Neurol. 1998, 154, 537-550. [CrossRef]

93. Greer, C.A. Golgi analyses of dendritic organization among denervated olfactory bulb granule cells. J. Comp. Neurol. 1987, 257, 442-452. [CrossRef]

94. Recio, J.S.; Weruaga, E.; Gomez, C.; Valero, J.; Briñón, J.G.; Alonso, J.R. Changes in the connections of the main olfactory bulb after mitral cell selective neurodegeneration. J. Neurosci. Res. 2007, 85, 2407-2421. [CrossRef]

95. Baker, H.; Greer, C.A. Region-specific consequences of PCD gene expression in the olfactory system. J. Comp. Neurol. 1990, 293, 125-133. [CrossRef] [PubMed]

96. Gómez, C.; Curto, G.G.; Baltanás, F.C.; Valero, J.; O’Shea, E.; Colado, M.I.; Díaz, D.; Weruaga, E.; Alonso, J.R. Changes in the serotonergic system and in brain-derived neurotrophic factor distribution in the main olfactory bulb of pcd mice before and after mitral cell loss. Neuroscience 2012, 201, 20-33. [CrossRef] [PubMed]

97. Airado, C.; Gómez, C.; Recio, J.S.; Baltanás, F.C.; Weruaga, E.; Alonso, J.R. Zincergic innervation from the anterior olfactory nucleus to the olfactory bulb displays plastic responses after mitral cell loss. J. Chem. Neuroanat. 2008, 36, 197-208. [CrossRef] [PubMed]

98. Valero, J.; Weruaga, E.; Murias, A.R.; Recio, J.S.; Curto, G.G.; Gómez, C.; Alonso, J.R. Changes in cell migration and survival in the olfactory bulb of the pcd/pcd mouse. Dev. Neurobiol. 2007, 67, 839-859. [CrossRef]

99. Chu, M.W.; Li, W.L.; Komiyama, T. Balancing the Robustness and Efficiency of Odor Representations during Learning. Neuron 2016, 92, 174-186. [CrossRef]

100. Díaz, D.; Lepousez, G.; Gheusi, G.; Alonso, J.R.; Lledo, P.M.; Weruaga, E. Bone marrow cell transplantation restores olfaction in the degenerated olfactory bulb. J. Neurosci. 2012, 32, 9053-9058. [CrossRef]

101. Díaz, D.; Gómez, C.; Muñoz-Castañeda, R.; Baltanás, F.; Alonso, J.R.; Weruaga, E. The olfactory system as a puzzle: Playing with its pieces. Anat. Rec. 2013, 296, 1383-1400. [CrossRef]

102. O'Gorman, S. Degeneration of thalamic neurons in "Purkinje cell degeneration" mutant mice. II. Cytology of neuron loss. J. Comp. Neurol. 1985, 234, 298-316. [CrossRef] [PubMed]

103. Kyuhou, S.-i.; Gemba, H. Fast cortical oscillation after thalamic degeneration: Pivotal role of NMDA receptor. Biochem. Biophys. Res. Commun. 2007, 356, 187-192. [CrossRef] [PubMed]

104. Chakrabarti, L.; Neal, J.T.; Miles, M.; Martinez, R.A.; Smith, A.C.; Sopher, B.L.; La Spada, A.R. The Purkinje cell degeneration 5J mutation is a single amino acid insertion that destabilizes Nna1 protein. Mamm. Genome 2006, 17, 103-110. [CrossRef] [PubMed]

105. LaVail, M.M.; Blanks, J.C.; Mullen, R.J. Retinal degeneration in the pcd cerebellar mutant mouse. I. Light microscopic and autoradiographio analysis. J. Comp. Neurol. 1982, 212, 217-230. [CrossRef] [PubMed]

106. Grau, M.B.; Masson, C.; Gadadhar, S.; Rocha, C.; Tort, O.; Sousa, P.M.; Vacher, S.; Bieche, I.; Janke, C. Alterations in the balance of tubulin glycylation and glutamylation in photoreceptors leads to retinal degeneration. J. Cell Sci. 2017, 130, 938-949. [CrossRef]

107. Okubo, A.; Sameshima, M.; Unoki, K.; Uehara, F. The ultrastructural study of ribosomes in photoreceptor inner segments of the pcd cerebellar mutant mouse. Jpn. J. Ophthalmol. 1995, 39, 152-161.

108. LaVail, M.M.; Gorrin, G.M.; Yasumura, D.; Matthes, M.T. Increased susceptibility to constant light in nr and pcd mice with inherited retinal degenerations. Investig. Ophthalmol. Vis. Sci. 1999, 40, 1020-1024.

109. Gardette, R.; Alvarado-Mallart, R.M.; Crepel, F.; Sotelo, C. Electrophysiological demonstration of a synaptic integration of transplanted purkinje cells into the cerebellum of the adult purkinje cell degeneration mutant mouse. Neuroscience 1988, 24, 777-789. [CrossRef]

110. Sotelo, C.; Alvarado-Mallart, R.M. Embryonic and adult neurons interact to allow Purkinje cell replacement in mutant cerebellum. Nature 1987, 327, 421-423. [CrossRef] 
111. Sotelo, C.; Alvarado-Mallart, R.M. Reconstruction of the defective cerebellar circuitry in adult purkinje cell degeneration mutant mice by Purkinje cell replacement through transplantation of solid embryonic implants. Neuroscience 1987, 20, 1-22. [CrossRef]

112. Sotelo, C.; Alvarado-Mallart, R.M.; Gardette, R.; Crepel, F. Fate of grafted embryonic purkinje cells in the cerebellum of the adult "purkinje cell degeneration" mutant mouse. I. Development of reciprocal graft-host interactions. J. Comp. Neurol. 1990, 295, 165-187. [CrossRef] [PubMed]

113. Gardette, R.; Crepel, F.; Alvarado-Mallart, R.M.; Sotelo, C. Fate of grafted embryonic purkinje cells in the cerebellum of the adult "purkinje cell degeneration" mutant mouse. II. Development of synaptic responses: An in vitro study. J. Comp. Neurol. 1990, 295, 188-196. [CrossRef] [PubMed]

114. Triarhou, L.C.; Low, W.C.; Ghetti, B. Serotonin fiber innervation of cerebellar cell suspensions intraparenchymally grafted to the cerebellum of pcd mutant mice. Neurochem. Res. 1992, 17, 475-482. [CrossRef]

115. Sotelo, C.; Alvarado-Mallart, R.M. Growth and differentiation of cerebellar suspensions transplanted into the adult cerebellum of mice with heredodegenerative ataxia. Proc. Natl. Acad. Sci. USA 1986, 83, 1135-1139. [CrossRef]

116. Chang, A.C.; Ghetti, B. Embryonic cerebellar graft development during acute phase of gliosis in the cerebellum of pcd mutant mice. Chin. J. Physiol. 1993, 36, 141-149.

117. Triarhou, L.C.; Zhang, W.; Lee, W.H. Graft-induced restoration of function in hereditary cerebellar ataxia. Neuroreport 1995, 6, 1827-1932. [CrossRef]

118. Triarhou, L.C.; Zhang, W.; Lee, W.H. Amelioration of the behavioral phenotype in genetically ataxic mice through bilateral intracerebellar grafting of fetal Purkinje cells. Cell Transplant. 1996, 5, 269-277. [CrossRef]

119. Zhang, W.; Lee, W.H.; Triarhou, L.C. Grafted cerebellar cells in a mouse model of hereditary ataxia express IGF-I system genes and partially restore behavioral function. Nat. Med. 1996, 2, 65-71. [CrossRef] [PubMed]

120. Recio, J.S.; Álvarez-Dolado, M.; Díaz, D.; Baltanás, F.C.; Piquer-Gil, M.; Alonso, J.R.; Weruaga, E. Bone marrow contributes simultaneously to different neural types in the central nervous system through different mechanisms of plasticity. Cell Transplant. 2011, 20, 1179-1192. [CrossRef] [PubMed]

121. Díaz, D.; del Pilar, C.; Carretero, J.; Alonso, J.R.; Weruaga, E. Daily bone marrow cell transplantations for the management of fast neurodegenerative processes. J. Tissue Eng. Regen. Med. 2019, 13, 1702-1711. [CrossRef] [PubMed]

122. Cendelin, J. Transplantation and Stem Cell Therapy for Cerebellar Degenerations. Cerebellum 2016, 15, 48-50. [CrossRef] [PubMed]

123. Torres-Aleman, I.; Barrios, V.; Lledo, A.; Berciano, J. The insulin-like growth factor I system in cerebellar degeneration. Ann. Neurol. 1996, 39, 335-342. [CrossRef] [PubMed]

124. Carrascosa, C.; Torres-Aleman, I.; Lopez-Lopez, C.; Carro, E.; Espejo, L.; Torrado, S.; Torrado, J.J. Microspheres containing insulin-like growth factor I for treatment of chronic neurodegeneration. Biomaterials 2004, 25, 707-714. [CrossRef]

125. Sanz-Gallego, I.; Rodriguez-de-Rivera, F.J.; Pulido, I.; Torres-Aleman, I.; Arpa, J. IGF-1 in autosomal dominant cerebellar ataxia-Open-label trial. Cerebellum Ataxias 2014, 1, 13. [CrossRef] [PubMed]

126. Pérez-Martín, E.; Muñoz-Castañeda, R.; Moutin, M.J.; Ávila-Zarza, C.A.; Muñoz-Castañeda, J.M.; Del Pilar, C.; Alonso, J.R.; Andrieux, A.; Díaz, D.; Weruaga, E. Oleoylethanolamide Delays the Dysfunction and Death of Purkinje Cells and Ameliorates Behavioral Defects in a Mouse Model of Cerebellar Neurodegeneration. Neurotherapeutics 2021. [CrossRef]

127. Henry, R.J.; Ritzel, R.M.; Barrett, J.P.; Doran, S.J.; Jiao, Y.; Leach, J.B.; Szeto, G.L.; Wu, J.; Stoica, B.A.; Faden, A.I.; et al. Microglial depletion with CSF1R inhibitor during chronic phase of experimental traumatic brain injury reduces neurodegeneration and neurological deficits. J. Neurosci. 2020, 40, 2960-2974. [CrossRef] 